\title{
Potential Applications of Carbohydrases Immobilization in the Food Industry
}

Fabiano Jares Contesini ${ }^{1, \dagger, *}$, Joelise de Alencar Figueira ${ }^{1, \dagger}$, Haroldo Yukio Kawaguti ${ }^{1, \dagger}$, Pedro Carlos de Barros Fernandes ${ }^{2, \dagger}$, Patrícia de Oliveira Carvalho ${ }^{3, \dagger}$, Maria da Graça Nascimento ${ }^{4, \dagger}$ and Hélia Harumi Sato ${ }^{1, \dagger}$

1 Laboratory of Food Biochemistry, Department of Food Science, College of Food Engineering, State University of Campinas (UNICAMP), Monteiro Lobato Street, 80, 13083-862, P.O. Box 6121, Campinas, SP, Brazil; E-Mails: joangelotti@gmail.com (J.A.F.); hkawaguti@gmail.com (H.Y.K.); heliah@fea.unicamp.br (H.H.S.)

2 Department of Bioengineering, Higher Technical Institute (IST), Avenida Rovisco Pais, 1049-001 Lisboa, Portugal; E-Mail: pedro.fernandes@ist.utl.pt

3 Laboratory of Multidisciplinary Research, University São Francisco, São Francisco de Assis Av, 218, 12916-900, Bragança Paulista, SP, Brazil; E-Mail: patricia.carvalho@usf.edu.br

4 Chemistry Department, Federal University of Santa Catarina, Florianópolis, Santa Catarina, 88040-900, Brazil; E-Mail: maria.nascimento@ufsc.br

$\dagger$ These authors contributed equally to this work.

* Author to whom correspondence should be addressed; E-Mail: fabiano.contesini@gmail.com; Tel.: +55-19-3521-2175; Fax: +55-19-3289-2832.

Received: 30 October 2012; in revised form: 17 December 2012 / Accepted: 18 December 2012 / Published: 11 January 2013

Abstract: Carbohydrases find a wide application in industrial processes and products, mainly in the food industry. With these enzymes, it is possible to obtain different types of sugar syrups (viz. glucose, fructose and inverted sugar syrups), prebiotics (viz. galactooligossacharides and fructooligossacharides) and isomaltulose, which is an interesting sweetener substitute for sucrose to improve the sensory properties of juices and wines and to reduce lactose in milk. The most important carbohydrases to accomplish these goals are of microbial origin and include amylases ( $\alpha$-amylases and glucoamylases), invertases, inulinases, galactosidases, glucosidases, fructosyltransferases, pectinases and glucosyltransferases. Yet, for all these processes to be cost-effective for industrial application, a very efficient, simple and cheap immobilization technique is required. 
Immobilization techniques can involve adsorption, entrapment or covalent bonding of the enzyme into an insoluble support, or carrier-free methods, usually based on the formation of cross-linked enzyme aggregates (CLEAs). They include a broad variety of supports, such as magnetic materials, gums, gels, synthetic polymers and ionic resins. All these techniques present advantages and disadvantages and several parameters must be considered. In this work, the most recent and important studies on the immobilization of carbohydrases with potential application in the food industry are reviewed.

Keywords: carbohydrases immobilization; amylases; invertases; inulinases; galactosidases; glucosidases; fructosyltransferases; pectinases; glucosyltransferases

\section{Introduction}

The food industry is a sector where biotechnology finds a wide application. Within this context, different groups of enzymes have potential applications in many industrial steps, including food processing. Carbohydrases represent a group of enzymes, which is among the most frequently used in the food industry. In the broadest sense, the term carbohydrase is considered to encompass diverse enzymes involved in hydrolysis and synthesis of carbohydrates, such as: amylases and invertases used in the production of syrups form starch and sucrose; $\beta$-glucosidase in the processing of fruit juices and wine, namely for flavor enhancement, and for oligosaccharide production; and glucosyltransferases for the synthesis of isomaltulose, fructosyltransferases and $\beta$-galactosidase for the production of prebiotics (Table 1) [1].

Table 1. Biotechnological applications of microbial carbohydrases in the food industry.

\begin{tabular}{lllc}
\hline \multicolumn{1}{c}{ Carbohydrase } & \multicolumn{1}{c}{ Microbial source } & \multicolumn{1}{c}{ Application } & Reference \\
\hline Amylases & Bacillus megaterium VUMB109 & Maltooligosaccharides production & {$[2]$} \\
Invertases & Sacharomyces cereviseae & Hydrolysis of sucrose & {$[3]$} \\
Inulinases & Aspergillus niger & Fructose syrup production & {$[4]$} \\
& Lactobacillus delbrueckii subsp. & Lactose hydrolysis in milk & {$[5]$} \\
$\beta$-galactosidase & bulgaricus ATCC 11842 & Synthesis of galactooligosaccharides & {$[6]$} \\
& Aspergillus oryzae & Enhancement of the amounts of free & \\
$\beta$-glucosidase & Rhizomucor miehei NRRL 5282 & phenolic antioxidants in sour \\
& & cherry pomace & {$[7]$} \\
Glucosyltransferase & Erwinia sp. & Isomaltulose production & {$[8]$} \\
\hline
\end{tabular}

Most of the carbohydrases applied in the food industry are obtained from microbial sources, such as bacteria, yeasts and fungi, since this approach allows for maximum consistency. Microorganisms grow faster and easier than mammalian and plant cells, and the enzyme production is neither influenced by climatic conditions or seasonal changes, nor by regulatory or ethical issues related to animal slaughter or tree or plant felling. Extracellular enzyme-producing microorganisms are preferred, since this simplifies downstream processing, hence further lowering costs [1,9]. 
A key issue when the industrial application of an enzyme is envisaged is cost-effectiveness. This takes into consideration both the production costs and the operational lifetime of the biocatalyst. The production of industrial enzymes by genetically modified microorganisms using recombinant DNA, which has been widely implemented, has made a significant contribution to cut down production costs. This approach allows for high levels of expression and purity to be achieved, even if industrial enzymes are made available as partially purified or bulk enzymes, unlike the highly purified enzymes required for analytical or diagnostic applications. Moreover, the use of recombinant DNA technology allows for the expression of enzymes that are naturally produced by pathogenic organisms and/or organisms with low expression levels and, together with directed evolution and bioinformatic tools, paves the way for protein engineering, so that the properties of the enzyme can be optimized for specific uses [9-11]. The quest for cheaper fermentative production media, such as agro-industrial, is another strategy for lowering the costs of enzyme production [12]. Despite all this, should the enzyme be discarded after its use, the cost-effectiveness of many enzyme-based processes could be severely jeopardized. Enzyme immobilization and use of the resulting immobilized biocatalyst may provide a sound approach to resolve this $[9,13,14]$. As can be seen in Table 2, several carbohydrases have been immobilized using different supports (Table 2).

Table 2. Carbohydrases immobilization using different immobilization techniques.

\begin{tabular}{|c|c|c|c|c|}
\hline Enzyme & Support & $\begin{array}{c}\text { Immobilization } \\
\text { method }\end{array}$ & $\begin{array}{c}\text { Improvement } \\
\text { compared to the free form }\end{array}$ & Reference \\
\hline$\alpha$-amylase & Functionalized glass beads & Covalent binding & $\begin{array}{l}\text { Better thermostability and } \\
\text { reuse after six runs }\end{array}$ & [15] \\
\hline Glucoamylase & Polyaniline polymer & Covalent binding & $\begin{array}{l}\text { Better thermostability and } \\
\text { higher stability in the } \\
\text { alkaline range }\end{array}$ & [16] \\
\hline Pullulanase & Magnetic chitosan beads & Covalent binding & $\begin{array}{l}\text { Higher relative activity, } \\
\text { stabilization of enzyme over } \\
\text { a broader pH range }\end{array}$ & [17] \\
\hline Inulinase & DEAE-Cellulose & Adsorption & Better thermostability & [18] \\
\hline Invertase & Calcium alginate gel capsules & Entrapment & $\begin{array}{l}\text { Better stability at high } \mathrm{pH} \\
\text { and temperatures }\end{array}$ & [19] \\
\hline$\beta$-Galactosidase & $\begin{array}{l}\text { Polysiloxane-polyvinyl } \\
\text { alcohol magnetic } \\
\text { (mPOS-PVA) composite }\end{array}$ & Covalent binding & $\begin{array}{l}\text { Higher operational and } \\
\text { thermal stability }\end{array}$ & [20] \\
\hline$\beta$-glucosidase & Eupergit C & Covalent binding & Improvement of the stability & [21] \\
\hline Pectinase & $\begin{array}{l}\text { Sodium alginate support using } \\
\text { glutaraldehyde }\end{array}$ & Covalent binding & $\begin{array}{l}\text { Higher thermostability and } \\
\text { reusability }\end{array}$ & [22] \\
\hline Fructosyltransferase & Eupergit C & Covalent binding & $\begin{array}{l}\text { Reuse for } 20 \text { batch reactions, } \\
\text { better stability at high } \mathrm{pH} \\
\text { and temperatures }\end{array}$ & [23] \\
\hline
\end{tabular}

Using immobilized enzymes enables the reuse of the biocatalysts, since they can be easily recovered, and it allows for continuous operation, which is clearly favored in an industrial environment. Moreover, immobilization may stabilize enzymes (although this does not always occur, 
namely if immobilization is random, rather than properly designed [24]), make enzymes less sensitive to environmental conditions; improve the control of the reaction (viz. altered selectivity or specificity), avoid product contamination with the enzyme and enhance enzyme activity (although, this latter feature is less common [13,14,24-27]). A review on whether improvement in activity, specificity and selectivity as a result of immobilization anchor on realistic issues or are only artifacts has been published recently, where these matters are critically addressed [26]. The stabilization of enzymes due to immobilization can be due to several factors. Immobilization inside a porous material prevents both interfacial interaction, resulting in the presence of air bubbles, shear stress due to stirring or organic-aqueous systems and interaction with macromolecules of the enzyme extract, that otherwise may lead to aggregation, autolysis or proteolysis [28-32]. When non-porous supports are used, and enzymes are thus immobilized on the external surface of the support particles, this protective effect was mimicked through the coating of the enzyme molecules with aldehyde dextran [33]. Rigidification of enzyme structure has also been shown to result from immobilization. For that purpose, both activated synthetic carriers are especially useful. These supports thus provide a high density of attachment sites to covalently immobilize the enzyme molecule through multi-point covalent attachment to several residues placed on the enzyme surface. As a result, conformational changes promoted by agents that are involved in enzyme inactivation are minimized [24,27,34] Stabilization of multimeric enzymes (D-amino acid oxidase, $\beta$-galactosidase, alcohol dehydrogenase) may also be achieved through immobilization, by preventing the dissociation of the enzyme in its subunits. Hence, binding of the different subunits is aimed at in $[24,27,35,36]$. This strategy has been shown to be particularly effective fro dimeric and trimeric enzymes when anchored on densely activated supports, again, typically epoxy- and glyoxyl-based supports, which prevent dissociation and enhance the overall rigidity of the enzyme [24,35,37]. For more complex structures, viz. tetrameric enzymes (ampicillin acylase or catalases) or multiprotein complexes, the combination of multipoint attachment in densely activated supports and additional cross-linking was shown to allow the binding of immobilized and non-immobilized subunits, hence stabilizing such structures [24,35,37]. Penalties commonly associated with immobilization are mass transfer limitations, costs associated with immobilization and eventual loss of intrinsicality [13,14,24-26]. Several parameters are important when industrial applications of the enzymes are considered. Particular relevance is given to mechanical strength, chemical and physical stability, hydrophobic/hydrophilic character, enzyme loading capacity and cost of the support and cost of the immobilization procedure [13,14,25,38].

The present work provides an overview of recent developments on the use of immobilized carbohydrases for application in the food industry.

\section{Enzyme Immobilization Techniques}

Enzyme immobilization techniques may be performed by: (a) binding of the enzyme to a prefabricated carrier; (b) entrapping or encapsulating the enzyme in a three-dimensional polymeric network formed in the presence of the enzyme; and (c) carrier-free methodologies that rely in the cross-linking of enzyme crystals (CLECs) or enzyme aggregates (CLEAs) with bifunctional reagents to produce macroparticles $[13,14,25]$. Furthermore, carrier-free methodology significantly reduces the amount of non-catalytic material that is used in enzyme formulations. Eventually, a mixture of two 
different techniques can be used, namely, combining: (a) CLEAs with entrapment [39]; (b) cross-linking with binding to a previously formed support [40]; (c) cross-linking and entrapment [41]; and (d) adsorption and covalent bonding [42,43].

Although the immobilization of enzymes has had by far an empiric nature, a more rational approach towards this approach has been gaining relevance. This anchors in having detailed insight of the structure of the enzyme molecule (viz. distribution of residues available for immobilization, distribution of hydrophilic/hydrophobic zones of the enzyme, electrostatic potential of the molecule, locus of the active site), but also of the morphological and chemical characteristics of the carrier. Dedicated software has also been developed that enables the generation of predictive models of immobilization efficiency [14,44]. Enzyme binding to a carrier may be carried out by physical adsorption or by covalent attachment. In the former case, hydrogen bonds, van der Waals forces, ionic bonding or hydrophobic interactions may be involved. Adsorption is easy and cheap to perform, and negligible enzyme deactivation is typically observed as an outcome of immobilization procedures. However, changes in substrate and salt concentration, enzyme load, flow rate, temperature or $\mathrm{pH}$ fluctuations easily lead to desorption and, consequently, enzyme leakage. Hence, constant operational conditions are required. On the other hand, desorption of enzymes at the end of the active life of the biocatalysts enables the regeneration and re-use of the carrier $[14,41,45,46]$.

Adsorption can be of particular interest in non-aqueous media, considering the intrinsic insolubility of the enzyme in organic solvents $[13,47]$. The fusion of the enzyme with a cationic, arginine-rich variant of a protein domain has been suggested in order to enhance the driving force for non-covalent binding to an anionic carrier. Furthermore, the methodology implemented also increased the selectivity of binding, since, at neutral $\mathrm{pH}$, most of the proteins used displayed a negative charge. Moreover, the charge asymmetry resulting from the introduction of the residue led to a preferred orientation of binding, so that unwanted interactions between the carrier surface and active site of the modified enzyme are not favorable [45]. Bolivar and Nidetzky [45] have also shown that under selected conditions, elution of these modified enzymes could be eluted from silica materials, which are widely used for enzyme immobilization, hence allowing carrier reuse.

Enzyme immobilization by covalent binding to an insoluble support is particularly advisable when the absence of enzyme in the product stream is a strict requirement, given the stable nature of the bonds established between active amino acid residues located on the surface of the enzyme and active functional groups present at the surface of the carrier [48]. A drawback to this approach is that it often involves the use of chemicals and/or operational conditions that are hazardous for enzyme activity, features that were particularly noticeable in the early developed carriers and methods [49]. This has been overcome through the use of less aggressive techniques and supports, namely with the introduction of pre-activated supports $[13,43,50]$. Commercially available epoxy activated supports (viz. Eupergit $^{\circledR}$, Sepabeads ${ }^{\circledR}$ ) were shown to provide adequate matrices for enzyme immobilization through a two step process. This involved a rapid and mild physical adsorption of the enzyme to the support, followed by a covalent binding between the adsorbed enzyme molecules and neighboring epoxide groups [14,51-53]. This first generation of epoxy supports displayed only moderate enzyme immobilization rates. Such behavior was noticed since only a small fraction of the epoxy groups on the support surface could be modified with amino groups, as a compromise between the rates of both enzyme adsorption and covalent immobilization [53]. Moreover, a high ionic strength environment 
was required for immobilization, often with a negative impact on enzyme stability. Again, since immobilization involved hydrophobic areas of the enzyme and hydrophobic supports, enzyme stability could be occasionally compromised [43,54]. Bearing in mind the two-step mechanism for the covalent immobilization of proteins on epoxy supports, a second generation of hetero-functional supports was thus developed. These combined two types of functional groups: one group enabling the physical adsorption of the enzymes (viz. by ion exchange or adsorption on immobilized metal-chelates), obtained by the modification of epoxy groups; and another group enabling the covalent immobilization of the enzymes (viz. epoxy groups). Enzymes can thus be adsorbed to the support through different phenomena and then covalently bound through linkage between the epoxy group and nucleophilic groups of the enzyme [42]. This broadened the range both of enzymes that could be immobilized from protein extracts and of operational conditions and avoided the need of hydrophobic supports, so that hetero-functional agarose, for instance, could be used. However, in the design of these supports, the extent of epoxy modification required a compromise for achieving high rates of both adsorption and covalent binding. Thus, the fraction of modified surface epoxy groups was relatively low, concomitantly leading to moderate overall enzyme immobilization rates. This was overcome by the use of supports, where the epoxy groups were deposited on a layer of ethylenediamine, which is covalently bound to the support (viz. Sepabeads EC) [50,53]. Such supports display both high fractions of amino groups and a high density of epoxy groups. The advantage of these supports over conventional and second-generation supports were highlighted while testing several enzymes (viz. $\beta$-galactosidase, glutaryl acylase) and assessing parameters, such as activity recovery and thermal stability [53]. A fourth generation of epoxy-based supports was developed, aiming for further control of immobilization. These supports contained a small fraction of thiol reactive groups, thiol being the most reactive nucleophiles in proteins, and a large density of epoxy groups [53]. Binding of either chemically or genetically modified enzymes can lead to a very stable biocatalyst, due to multi-point or site-directed rigidification [55]. This strategy, involving the manipulation of the enzyme surface to promote a more efficient multi-point attachment to the support through the two step process, has been implemented for other supports, such as glyoxyl-activated supports. These supports have been shown to promote stronger multi-point covalent attachment than epoxy-based supports, thus enhancing protein stabilizations [56-58]. Further developments on the design of supports allowing for multi-point covalent attachments and their combined use with site-directed mutagenesis of enzymes to further improve immobilization have been reviewed recently [59].

Entrapment/encapsulation of enzymes entails the occlusion of enzyme molecules within a polymeric network, while allowing for the flow of substrate(s) and product(s). This methodology mostly involves biocompatible materials and mild conditions, but the resulting carriers may be prone to enzyme leakage, hence pre- or post-treatment may be required. The polymeric networks can be of a dense (entrapment) or hollow (encapsulation) nature, and be made of polymers, viz. natural gelling polysaccharides, such as alginate, carrageenan, chitosan or pectin, proteins, such as gelatin, and synthetic polymers, such as polyvinyl alcohol, or sol-gel composites [29,34]. The latter are chemically inert silica-based materials, made out of tetraalkoxysilanes, which can be shaped on demand and display high thermal and mechanical stability. Care must be given in the methodology for producing sol-gel carriers, so as to avoid restricted diffusion of substrate to the enzyme, as a result of the low porosity of the support $[13,60,61]$. 
Cross-linking of enzymes for application in bioconversion processes relies on the formation of enzyme aggregates. CLEAs preparation usually starts with the generation of enzyme aggregates. To achieve this, a precipitant, viz. acetone, ammonium sulfate, ethanol or 1,2-dimethoxyethane, is added to the enzyme solution, after which the cross-linking agent is added. Usually, glutaraldehyde is used, since it is cheap and widely available. Although the chemistry of the process is not fully understood, it is established that the free amino groups of lysine residues on the surface of neighboring enzyme molecules react with oligomers or polymers of glutaraldehyde that result from inter- and intra-molecular aldol condensations. The cross-linking process is $\mathrm{pH}$-dependent. CLEAs formation may also take place in the presence of additives (viz. magnetic nanoparticles, given polymers, bovine serum albumin) to convey smart biocatalysts, with tunable physical properties or as protective agents. Co-aggregation of bovine serum albumin (BSA) with lipase was shown to increase enzyme activity and recovery [62]. These authors identified a range of BSA concentration that allowed for an optimum level of cross-linking with glutaraldehyde increase in transesterification activity. Beyond such range of BSA concentration, there was either excessive cross-linking, due to lack of free amino groups, or an excess of amino groups available, ultimately preventing the required cross-linking of lipase molecules. The authors used the same approach for the preparation of co-aggregates of penicillin acylase and BSA, leading to a CLEA with twice the catalytic efficiency and improved thermal stability, when compared with CLEA prepared without BSA [62]. Dong and co-workers also used BSA to increase the content of lysine residues and, concomitantly, optimize the cross-linking efficiency, for the production of CLEAs of aminoacylase [63]. These authors observed an increase in activity recovery as a result of using BSA as additive in the preparation of CLEAs, since it allowed for more effective cross-linking. Still, care had to be taken on the mass ratio of gluataradehyde:enzyme, since when it increased from 0.75 to 1 , a decrease in the specific activity was also observed. This behavior could be due to an increased fraction of enzyme inactivated or to tightening of CLEAs, hence enhanced diffusion resistances. Dong et al. also reported an increase in the thermal stability of CLEAs produced using BSA as additive when compared to CLEAs prepared without this proteic feeder. This behavior was tentatively ascribed to deficient cross-linking in the later case, resulting in release of aminoacylase from the aggregate when exposed to high temperature. On the other hand, co-aggegates of laccase with BSA displayed lower activity, but higher stability than CLEAs without BSA. The lower activity of the co-aggregates was ascribed to shielding of the active site, as well as to mass transfer limitations. The higher stability of the co-aggregates was associated to the microenvironment created by significant amounts of BSA surrounding laccase. This favored cross-linking and decreased the entropy of the enzyme denatured state [64]. A different approach to overcome a deficient cross-linking, due to a low number of reactive groups on the surface of the enzyme, was suggested by López-Gallego and co-workers [65]. These authors carried out the aggregation of glutaryl acylase in the presence of polyethyleneimine. In the process, the amino groups of the polymer are brought closer to the scarce primary amino groups on the enzyme surface, promoting their cross-linking. This led to CLEAs with enhanced thermal stability when compared to the free enzyme, due to the rigidification of the tertiary structure of the enzyme, resultant of the cross-linking.

In order to prevent CLEAs deactivation in the presence of organic solvents, Wilson and co-workers produced co-aggregates of penicillin $\mathrm{G}$ acylase and polyethyleneimine and dextran sulfate [66]. These polymers created an extremely hydrophilic coating of the CLEAs. The authors were able to establish 
that the hydrolytic activity of the polymer coated CLEAs decreased with an increase in the protein:polymer mass ratio and with the increase in the chain-length of the polymers, which they related to diffusion limitations. Polymer coated CLEAs displayed higher operational stability in the presence of organic media than simple CLEAs. Such increase, based in the half-life, could be of 16- to 26-fold, whether polymers with molecular weights either within 5000-25,000 Da or with 1,000,000 Da were used, respectively. This behavior was related to the larger polymers covering the enzyme in a more efficient manner. On the other hand, the thermal stability of CLEAs was not altered by polymer coating, which further suggested that increased stability of coated CLEAs in an organic environment is due to the hydrophilic microenvironment surrounding the enzyme, rather than to a more rigid conformation of the enzyme.

In order to overcome the relatively mechanical stability of CLEAs, the aggregates have been encapsulated in rigid polymeric materials, such as a polyvinyl alcohol-based hydrogel, LentiKats ${ }^{\circledR}$ [67]. Although the encapsulation was shown to decrease by $40 \%$, the activity of penicillin $\mathrm{G}$ acylase aggregates, due to diffusion limitations, in the encapsulation improved the thermal stability of the CLEA in the presence of organic solvents. This was due to a hydrophilic microenvironment surrounding the enzyme, created by the hydrogel [68].

Kim and co-workers developed a novel approach to produce enzymatic nanocomposites through the adsorption of either $\alpha$-chymotrypsin or lipase in hierarchically ordered, mesocellular, mesoporous silica, followed by cross-linking with glutaraldehyde. The resulting magnetic CLEAs were shown to be easily recoverable from the reaction medium by the use of a magnet, retained their integrity, even under harsh shaking condition, unlike the nanocomposites without glutaraldehyde treated, and could be recycled for repeated batch runs without significant loss of catalytic activity [69].

\section{Immobilized Enzymes in Syrup Production}

\subsection{Amylolytic Enzymes}

Amylases compose one important group of enzymes that can be applied in the production of maltose, maltodextrin, glucose and high fructose syrups using starch as substrate (Figure 1). The production of glucose syrups involves two steps. Firstly, the starch is liquefied where the $\alpha$-amylase partially hydrolyzes starch to maltodextrins and, secondly, saccharification happens where the low dextrose equivalent (D.E.) syrup is completely converted to glucose by glucoamylase [70]. Pullulanase, a starch debranching enzyme, can be also used in the later process in addition to glucoamylase [71]. Several works describe the immobilization of amylases. One particular issue that should be taken into consideration in the design of immobilized amylases is the bulky nature of the starch substrate, which may reach up to $80 \mathrm{MDa}$ [72]. Hence, the small pore sizes of several commonly used supports, under $100 \mathrm{~nm}$, may cause significant diffusion resistances and hinder the access of the starch molecules to the active site, hence leading to low overall reaction rates $[49,72]$, although this is not always observed,. These can be reduced by use of matrix supports with large pore diameters [49]. This pattern was observed by Ivanova and co-workers when covalently binding amylase $\mathrm{G}$ from Bacillus licheniformis to Sperosils with pore sizes within $460 \mathrm{~nm}$ to $8 \mathrm{~nm}$, to perform starch hydrolysis, although some deviation was observed when amylase A was immobilized [73]. Still, 
no mass transfer limitations were observed when the much smaller amylopectin was used as substrate. Shewale and Pandi immobilized $\alpha$-amylase in a super-porous support (pore diameter about $3 \mu \mathrm{M}$ ), CELBEADS, aiming to capitalize on this matter for starch hydrolysis [74]. Still, the apparent $K_{\mathrm{m}}$ was 4.5-fold higher than that of the free enzyme, a feature the authors ascribed either to the structural changes in the enzyme occurring as a result of the covalent immobilization or still persisting diffusion limitations and steric hindrances limiting the access of the substrate to the active site. Nevertheless, immobilization enhanced thermal stability, and moreover, the immobilized enzyme retained full activity after eight batches of hydrolysis. These results also allow pointing out that modifications in the apparent affinity of the immobilized enzyme towards the substrate may not solely reflect changes in mass transfer. Also, a direct match of different works, when aiming to compare the impact of immobilization on the access to the active site of the bulky substrate, proves a bit difficult, since the actual average size of the substrate is not always referred, and this may have a clear significance.

Figure 1. Hydrolysis of starch using different amylolytic enzymes.

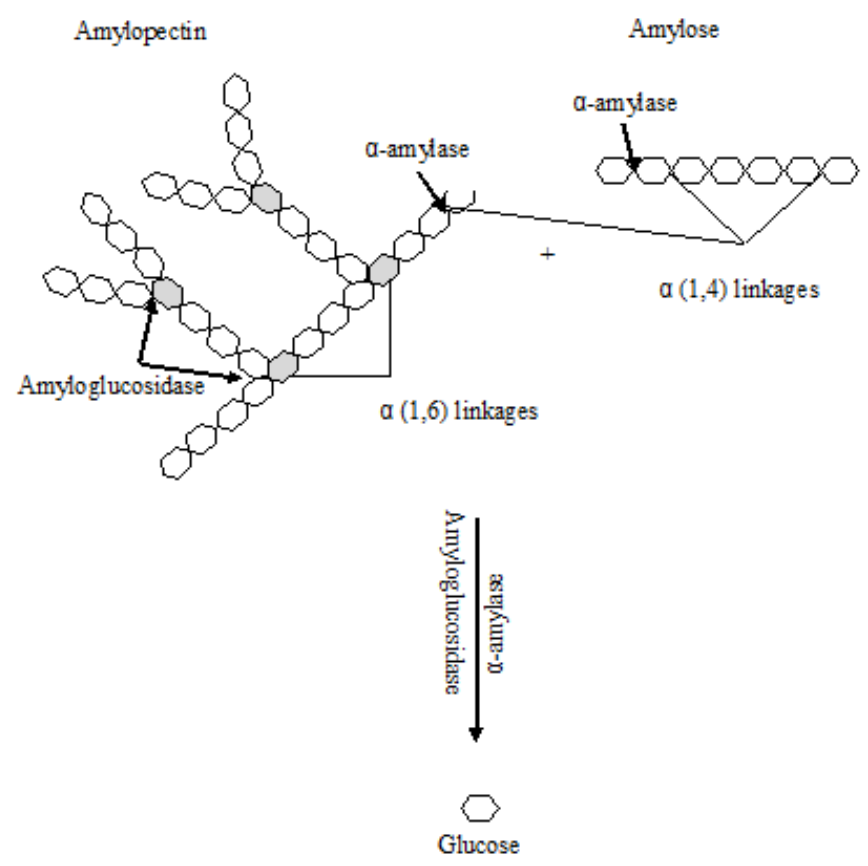

Most of the recent studies on $\alpha$-amylase immobilization use adsorption and covalent binding techniques. In the work of Singh and Kumar [75], carboxymethyl tamarind gum, a derivative of the cheap and plentiful tamarind seed polysaccharide with enhanced water solubility, initiated and catalyzed the sol-gel polymerization of tetramethoxysilane. The outcome was a monolithic silica-polysaccharide nanohybrid, upon which $\alpha$-amylase was immobilized by adsorption. The resulting catalytically-active nanohybrid was thoroughly characterized through different analytical methods, viz. BET, FTIR, SEM, TGA and XRD, and applied to the hydrolysis of soluble potato starch to glucose syrup. The optimum $\mathrm{pH}$ and temperature for the hydrolysis reaction were $\mathrm{pH} 5.0$ and $40{ }^{\circ} \mathrm{C}$, respectively. The kinetic parameters, $K_{\mathrm{m}}(4.261 \mathrm{~g} / \mathrm{L})$ and $V_{\max }\left(2.55 \mathrm{~mol} \mathrm{~mL}^{-1} \mathrm{~min}^{-1}\right)$, for the immobilized amylase were found favorable compared to the corresponding values obtained for the free enzyme $\left(K_{\mathrm{m}}=6.269 \mathrm{mg} / \mathrm{mL}, V_{\max }=1.53 \mathrm{~mol} \mathrm{~mL}^{-1} \mathrm{~min}^{-1}\right)$, despite the narrow size $(6.1 \mathrm{~nm})$ of the pores of the supports. The authors suggest that the observed changes in the kinetic parameters as a 
result of immobilization result from a positive distortion of the enzyme assembly. Moreover, no steric hindrances were considered to be present that restrained the access of the substrate to the active center. The enzymatic activity of the nanohybrid matrix remained stable for up to 90 days [75].

The $\alpha$-amylase from Aspergillus oryzae was immobilized on Magnetic poly(2-hydroxyethylmethacrylate)/Cibacron blue [mPHEMA]/CB beads by adsorption. The authors observed that the adsorbed amounts of $\alpha$-amylase per unit mass of magnetic beads reached a plateau value at about $1.0 \mathrm{mg} / \mathrm{mL}$ at $\mathrm{pH} 5.0$. The optimum $\mathrm{pH}$ for catalytic activity for free and immobilized enzyme was 7.0 and 8.0, respectively, and catalytic parameters remained almost unaltered as a result of immobilization. In this case, the magnetic particles had an average pore size of $814 \mathrm{~nm}$, which would contribute to reducing mass transfer limitations. The thermal stability of the immobilized enzyme was higher than the free form. After 35 days of storage at $4{ }^{\circ} \mathrm{C}$, the free $\alpha$-amylase lost all of its activity, whereas the immobilized enzyme lost approximately $27 \%$ of its activity during the same period. Moreover, enzyme adsorption-desorption cycles onto/from [mPHEMA]/CB beads were repeated up to five times. These studies showed that there was no significant reduction in the adsorption capacity of the beads, which could thus be repeatedly used in enzyme immobilization [76].

However, and given the simplicity and mild conditions of hydrogel encapsulation, research is still carried out aiming to improve this technique for application to $\alpha$-amylase. An example is the recent work by Talekar and Chavare, aimed at identifying the optimum conditions for producing an $\alpha$-amylase biocatalyst entrapped in calcium alginate for starch hydrolysis [77]. These authors were able to establish this using 3\% $(w / v)$ alginate, $1 \mathrm{M}$ calcium chloride and $120 \mathrm{~min}$ of curing time; an activity recovery of $90 \%$ was obtained, which may be the result of a tighter network, which minimizes enzyme leakage. The resulting biocatalyst displayed enhanced thermal stability, and the kinetic parameters did not differ significantly from the free form, suggesting negligible mass transfer resistances and no structural enzyme modifications as a result of immobilization. Reusability proved, however, a bit disappointing, since after 10 cycles, the activity decreased to about $35 \%$ of the initial value. Moreover, a reaction-diffusion mathematical model has been recently developed to simulate starch hydrolysis promoted by calcium alginate entrapped $\alpha$-amylase, in a process carried out in a packed-bed reactor [72].

Carpio et al. [78] studied the glucoamylase immobilization and its subsequent use in cassava starch hydrolysis. The enzyme was immobilized onto chicken bone particles, and some parameters, such as $\mathrm{pH}$, ionic strength, particle size and enzyme load, were evaluated. 270 units of glucoamylase were adsorbed per gram of support, and the optimal temperature and thermal stability of immobilized enzyme were only slightly different from those of the free enzyme, while the optimal $\mathrm{pH}$ became more acidic by about one unit. The immobilized biocatalyst was used for the production of high glucose syrup from liquefied cassava starch. The process was implemented at bench scale in a batch process using a stirred-tank reactor. Similar conversions to those achieved with soluble enzymes, and corresponding to $98 \mathrm{DE}$, were reached, until the third batch, and over $90 \mathrm{DE}$ were observed until the 25th batch.

The glucoamylasefrom Aspergillus niger was immobilized onto functionalized magnetic SBA-15 (FeSBA-15) as a regenerated support through metal-ion affinity interactions in the work of Zhao et al. [79]. The authors observed that the thermal stability of immobilized glucoamylase was much better than the soluble form. This behavior was ascribed to the enhanced enzyme rigidity 
conveyed by the enzyme binding to the carrier, thus preventing unfolding and conformation transition of the enzyme at high temperatures.

Pullulanase from Bacillus acidopullulyticus was covalently immobilized onto the hydrophobic synthetic macroporous resin Duolite XAD761 through the formation of Schiff bases [80]. The authors optimized the immobilization procedures, namely the incubation time and glutaraldehyde concentration for activation of the resin and enzyme loading and coupling time. As an outcome of immobilization, the optimum $\mathrm{pH}$ for activity was shifted from 5.0 to 5.5, and the temperature optimum for activity increased from 50 to $60^{\circ} \mathrm{C}$, as compared to the free form. The immobilized biocatalyst also displayed enhanced thermal stability as compared to the free enzyme. The substrate specificity was not altered as a result of immobilization, but the $K_{\mathrm{m}}$ values for the substrates assayed (pullulan, soluble starch and dextran) increased. The authors ascribed this feature to steric hindrances or to conformational changes of the enzyme molecules as an outcome of immobilization. The immobilized catalyst was reused throughout 35 consecutive cycles for pullulan $(0.44 \% \mathrm{w} / \mathrm{v}$ solution) hydrolysis. The percent hydrolysed was reduced to about $80 \%$ after 12 cycles, and after 35 cycles, it was reduced to a little under $30 \%$ [80]. The same immobilized biocatalyst was also used for the development of a continuous flow reactor, again using pullulan hydrolysis as a model system. Continuous operation was carried out throughout 32 days. After 15 days of operation, $80 \%$ hydrolysis was observed, but this gradually decreased to about $50 \%$ after 31 days of operation. At this point, the activity of the immobilized biocatalyst was also shown to have achieved its half-life [81].

Recently, Talekar et al. [82] prepared spherically-shaped magnetic CLEAs of $\alpha$-amylase by cross-linking enzyme aggregates with amino-functionalized magnetite nanoparticles. The inclusion of magnetic particles eased biocatalyst recovery from the reaction media. Moreover, it allowed for full recovery of activity during immobilization, whereas the use of simple CLEAs only allowed for $45 \%$ activity recovery. Both simple CLEAs and magnetic CLEAs displayed a shift in optimal $\mathrm{pH}$ towards more acidic values, and the optimal temperature of magnetic CLEAs was higher than that of simple CLEAs and of free enzymes. Moreover, the enzyme affinity to the substrate increased as a result of immobilization in either CLEA. Both storage and thermal stability of $\alpha$-amylase were enhanced as a result of immobilization in magnetic CLEAs, which were also reused for six cycles without any decay in the initial activity.

\subsection{Invertases}

One important type of sugar syrup is the inverted sugar syrup. It is broadly used in the food industry, since it produces denser solutions compared to sucrose, showing lower crystallization and growth of microorganisms. Furthermore, when compared to sucrose solution, inverted sugar syrup is $20 \%$ sweeter and has a lower freezing point and higher affinity for water [83]. This syrup can be obtained through the hydrolysis of sucrose syrups with invertase. In the use of the enzyme, the immobilized form is preferred, since it presents several advantages, such as reusability [84]. Some recent works focus on covalent binding techniques.

In the work of Cadena et al. [85], polyurethane rigid adhesive foam was used to covalently immobilize invertase for application in an enzymatic bioreactor. Immobilization increased the enzyme affinity to the substrate, as suggested by the decrease in $K_{\mathrm{m}}$ from $61.2 \mathrm{mM}$ to $46.5 \mathrm{mM}$. On the other 
hand, a 10-fold decrease in the turnover rate resulted from immobilization, possibly a consequence of diffusion restriction of the substrate to the immobilized biocatalyst. The immobilized enzyme retained $50 \%$ of the initial activity after eight months of storage at $4{ }^{\circ} \mathrm{C}$, and no microbial contamination was observed. The best results for production of invert sugar syrup under operation of the packed bed were obtained with an up-flow rate of $0.48 \mathrm{~L} / \mathrm{h}$, leading to an average conversion of $10.6 \% \mathrm{~h}^{-1}$ at a feeding rate of $104 \mathrm{~h}^{-1}$.

The extracellular thermostable invertase from Aspergillus awamori was immobilized on acetic acid-solubilized chitosan by covalent binding using glutaraldehyde. This enzyme preparation was efficiently and continuously applied in a packed bed reactor to the production of high-fructose syrup from sucrose. At $50{ }^{\circ} \mathrm{C}$ and $\mathrm{pH} 6$, an extract initially containing $139.2 \mathrm{~g} / \mathrm{L}$ total sugar with $78.6 \mathrm{~g} / \mathrm{L}$ sucrose at a flow rate of $17 \mathrm{~mL} / \mathrm{h}$ was applied, resulting in a conversion factor of 0.95 and a fructose content in the syrup of $69 \mathrm{~g} / \mathrm{L}[86]$.

Invertase was also covalently immobilized on glass-ceramic support (GCS). The immobilized biocatalyst was shown to retain $100 \%$ of the initial activity after nine reuses. The optimum $\mathrm{pH}$ and temperature for enzyme activity were not affected by immobilization, but the $K_{\mathrm{m}}$ increased 13.5 times, suggesting mass transfer resistances. Yet, when a packed bed reactor was operated in an alternate flow regime (alternation of down-flow and up-flow), it outperformed the up-flow and down-flow regime when the time course of sucrose hydrolysis was considered $[87,88]$.

Yeast invertase was also covalently bound with glutaraldehyde to activated carbon previously treated with urea and dimethyl formamide. The optimum $\mathrm{pH}$ for activity was shifted from 4.0 to 6.0 as a result of immobilization, whereas the temperature optimum decreased from $50{ }^{\circ} \mathrm{C}$ to $30{ }^{\circ} \mathrm{C}$. The maximum activity for both free and immobilized enzyme was observed for a sucrose concentration of $625 \mathrm{mM}[89]$.

Cell wall invertase modified with glutaraldehyde was entrapped in calcium alginate beads. Immobilization was shown to have broad $\mathrm{pH}$ and thermal stability, as well as a broader $\mathrm{pH}$ optimum (4.0 to 5.5) and temperature optimum $\left(55\right.$ to $70{ }^{\circ} \mathrm{C}$ ), as compared to the free form ( $\mathrm{pH}$ between 4.0 and 5.0 and temperature of $60{ }^{\circ} \mathrm{C}$ ). Continuous operation with a packed-bed reactor allowed for $95 \%$ inversion of $60 \%(w / w)$ sucrose solution and for a productivity of $3844 \mathrm{~kg}$ of inverted sugar per $\mathrm{kg}$ of immobilized biocatalyst after one month of operation [90].

Invertase was also entrapped in polyvinyl alcohol-alginate beads treated with sodium sulfate for the hydrolysis of liquid pineapple waste. The temperature optimum for activity remained unaltered at $50{ }^{\circ} \mathrm{C}$, but the $\mathrm{pH}$ optimum was shifted from 5.0 to 4.0 as an outcome of immobilization. This feature was ascribed to the higher proton concentration inside the beads as compared to the bulk solution, resulting from the dissolved boric acid present in the beads. The apparent affinity of the enzyme to the substrate increased significantly, due to favored mass transfer effects, and the maximum reaction rate increased, as a result of enhanced enzyme-support affinity. The beads were effectively used in 14 cycles for the full hydrolysis of $1 \%(w / v)$ sucrose solution and were stored at $4{ }^{\circ} \mathrm{C}$ for 60 days with no decay in activity. Moreover, the immobilized invertase successfully converted $91.4 \%$ of sucrose present in pineapple waste to glucose [91].

Porous CLEAs of invertase have recently been prepared. The process was carried out by using starch as a pore-making agent to a crude invertase solution, promoting co-precipitation with ammonium sulfate, and cross-linking the co-precipitate with glutaraldehyde. The kinetic parameters 
for sucrose hydrolysis remained unaltered as a result of immobilization, suggesting no mass transfer limitation nor deleterious effects on enzyme structure [92].

\subsection{Inulinases}

Inulin is a polyfructan found in many types of plants, and it is recognized as a source for the production of both ultra-high fructose syrup [10] and inulooligosaccharides [93]. This is very relevant, since fructose presents GRAS (Generally Recognized as Safe) status. Inulin is easily hydrolysed by exoinulinase (-D-fructan fructanohydrolase, E.C. 3.2.1.80) and endoinulinase (2,1-D-fructan fructanohydrolase, E.C. 3.2.1.7). Exoinulinase hydrolyzes inulin by splitting off the terminal fructosyl units by cleaving the glycosidic linkages to the polysaccharide moiety. On the other hand, exoinulinases were distinguishable from endoinulinase by their ability to hydrolyze sucrose [94]. Hence, fructanohydrolase from microbial sources plays an important role in the hydrolysis of inulin for its commercial production.

The enzymatic process is preferred over the chemical hydrolysis, due to the drawbacks, like production of unwanted by-products and color-forming compounds [95]. Santa et al. [96] used sol-gel immobilized inulinase for the hydrolysis of inulin to fructose. The authors obtained porous xerogel particles with dimensions in slight excess of $10 \mu \mathrm{M}$ and an immobilization efficiency of roughly $80 \%$. According to the estimated kinetic parameters, the immobilization in sol-gel did not alter the native enzyme conformation, yet the entrapment resulted in mass transfer limitations. Regarding the operational stability, the sol-gel immobilized biocatalyst was used in more than 20 consecutive batches of $24 \mathrm{~h}$ without a significant decrease in product yield. These results could be considered very interesting, regarding industrial application of enzymes, compared to free enzymes that cannot be reused.

Singh et al. [97] reported the immobilization of the partially purified extracellular exoinulinase from Kluyveromyces marxianus YS-1 on Duolite A568. The biochemical characteristics of the immobilized enzyme were slightly different from the soluble enzyme. The optimum pH for enzyme activity, 5.5, was not altered as a result of immobilization, whereas the latter led to a shift in the optimal temperature from $50{ }^{\circ} \mathrm{C}$ to $55^{\circ} \mathrm{C}$. The immobilized biocatalyst retained more than $90 \%$ of its original activity after incubation for $3 \mathrm{~h}$ at $60{ }^{\circ} \mathrm{C}$. The activity of the free enzyme was reduced to $10 \%$ under the same conditions, indicating an improvement in the thermal stability of the biocatalyst after immobilization. When the immobilized biocatalyst was applied in four-hour batch runs for the preparation of high fructose syrup from raw and pure inulin, fructose yields of 39.2 and $40.2 \mathrm{~g} / \mathrm{L}$ were reported. When recycling the biocatalysts, the percent of hydrolysis of a $5 \%(w / v)$ inulin solution decreased from a little under $85 \%$ to close to $60 \%$ after 10 cycles. The percent of hydrolysis decreased henceforth at a lower pace to attain about $40 \%$ after 55 cycles. The same immobilized biocatalyst was used in a continuous flow packed-bed reactor for the hydrolysis of a $5 \%(w / v)$ solution of inulin at $55{ }^{\circ} \mathrm{C}$, with a residence time of $1.25 \mathrm{~h}$. After 21 days of operation, the percent of hydrolysis and the volumetric productivity decreased from $100 \%$ and $44.5 \mathrm{~g} / \mathrm{L} / \mathrm{h}$ to $84 \%$ and $37 \mathrm{~g} / \mathrm{L} / \mathrm{h}$, respectively. The reactor was operated for a total of 75 days, where the percent of hydrolysis was $50 \%$ and the volumetric productivity had decreased to about $20 \mathrm{~g} / \mathrm{L} / \mathrm{h}$. The reactor was also operated for the hydrolysis of raw inulin, but it remained operational for only 11 days [98]. 
Basso et al. [44] carried out the rational immobilization of inulinase on Sepabeads EC-EP (oxirane group) and EC-HA (amino group), based on homology modeling, docking and molecular dynamics. The percent of bound protein was slightly higher in the latter $(82 \%)$ than in the former $(77 \%)$ and so was the activity, with $285 \mathrm{U} / \mathrm{g}_{\text {dry support }}$ for EC-HA support and $205 \mathrm{U} / \mathrm{g}_{\text {dry support }}$ for EC-EP support. Accordingly, the former displayed higher reaction rates for the hydrolysis of a $1 \%(w / v)$ inulin solution than the latter. However, oxirane-based supports allowed for higher final fructose yield (90\%) than the amino-based supports. Inulinase immobilized in the oxirane-based supports was then used to compare the performance of a fluidized bed reactor, operating in a closed cycle configuration, with that of a batch reactor for the hydrolysis of a $1 \%(w / v)$ inulin solution [99]. The authors were able to establish that in a range of flow rates within 1.6 and $2.4 \mathrm{~L} / \mathrm{h}$, external mass transfer effects were not significant, reaction kinetics being, instead, the controlling step. The performance of the fluidized bed reactor was marginally lower than that of the batch reactor, since after seven hours of operation, the former produced $5.4 \mathrm{~g} / \mathrm{L}$ fructose, compared to $6.4 \mathrm{~g} / \mathrm{L}$ fructose for the latter.

The immobilization of inulinase of $K$. marxianus var. bulgaricus was performed by entrapment in gelatin followed by cross-linking with glutaraldehyde. The optimum $\mathrm{pH}$ for immobilized inulinase was 3.5, and the optimum temperature was $60{ }^{\circ} \mathrm{C}$ [100]. Ettalibi and Baratti [101] have immobilized commercial inulinase preparation onto glass beads of different porosities by amination of glass beads with 3-aminopropyl triethanoxysilane, activation with glutarldehyde and incubation with inulinase solution. The half-life of the immobilized enzyme was 350 days at $50{ }^{\circ} \mathrm{C}$ with $2 \mathrm{M}$ sucrose solution. The immobilized cell system of Kluyveromyces marxianus had up to $85 \%$ residual activity and the immobilized enzyme was thermostable at $65{ }^{\circ} \mathrm{C}$ [102]. The residual activity in glutaraldehyde-treated beads after five cycles was up to $83 \%$, which was much higher than that of untreated beads (39\%). Enhanced recovery of $K$. marxianus inulinase was made using anionic resin Streamline DEAE, and a maximum adsorption of about $1428 \mathrm{U} / \mathrm{mL}$ was recorded [103].

Continuous production of oligofructose syrup from Jerusalem artichoke juice using immobilized A. niger endoinulinase on chitin has been reported [104]. The enzyme was covalently bound to the carrier chitosan using glutaraldehyde with an activity recovery of $66 \%$. Immobilization leads to a shift in $\mathrm{pH}$ optimum from 4.5-5.0 to 5.5-6.0. Such shifts in $\mathrm{pH}$ optima after immobilization have been reported in other inulinases as well [100,101]. Immobilized endoinulinase also showed a higher temperature optimum of $65{ }^{\circ} \mathrm{C}$ than free enzyme $\left(60{ }^{\circ} \mathrm{C}\right)$. Such increase has also been noticed in temperature optima of an immobilized preparation of endoinulinase from Pseudomonas $200 \mathrm{sp}$. and A. ficuum by $2.5^{\circ} \mathrm{C}$ and $10^{\circ} \mathrm{C}$, respectively $[101,105]$. On the other hand, the affinity of the enzyme towards inulin was not affected by immobilization. Both free and immobilized enzyme preparations were stable for one year, when stored at $4{ }^{\circ} \mathrm{C}$. Under continuous hydrolysis of inulin substrates, viz. Jerusalem artichoke juice or dahlia inulin, in a packed-bed reactor operating at $60{ }^{\circ} \mathrm{C}$ and $\mathrm{pH} 5.5$, a half-life of 48 days was estimated. Substrate solutions in a range within $2.7 \%(w / v)$ to $25 \%(w / v)$ were fed to the column. FOS effluent was composed mostly of oligofructose molecules with a degree of polymerization (DP) between 3 and 7, suggesting that fructan molecules of a higher degree of polymerization (DP8 and more) were hydrolyzed. The DP was influenced both by substrate nature and concentration. Typically, an increase in the latter led to a decrease in the relative amount of products with DP3 and an increase in the relative amount of products with higher DP. 


\section{Immobilized Carbohydrases in the Beverage Industry}

Many criteria should be adopted to choose supports for use in industrial processes, such as atoxicity (food grade), low cost and ready availability, ease of use, chemical inertia (under conditions of use), non-biodegradability and, lastly, the ability of the support to react either directly or via a simple and inexpensive activation method [106].

Several precursors of the aromatic components of wines, juices, musts and other alcoholic drinks are monoterpenes (geraniol, nerol, citronellol, linalool, $\alpha$-terpineol, etc.) in di-glycosidic form. They contain $\beta$-D-glucopyranose bound directly to aglycon and/or other sugars, including $\alpha$-L-rhamnopyranose and $\alpha$-L-arabinofuranose [107].

These conjugate compounds are not volatile and are generally soluble in water, being perceived only by the consumer's olfactory mucosa following removal of the carbohydrate moiety, by acid or enzymatic hydrolysis, that releases the volatile part (terpenols, sesquiterpenes, nor-isoprenoids, etc.) [108]. Glycosidases are used to increase the aroma of wines and other juices by sequential hydrolysis of the glycosides bound to the volatile compounds [109].

Spagna et al. [110] immobilized several glycosidases ( $\beta$-D-glucopyranosidase, $\alpha$-L-arabinofuranosidase, $\alpha$-L-rhamnopyranosidase), purified from an Aspergillus niger enzyme preparation by entrapment in chitosan gels and subsequent cross-linking with glutaraldehyde. The authors aimed to assess the feasibility of applying the immobilized biocatalyst in the wine-making and fruit-juice processing industry. The authors tested the addition of various agents in order to improve physical and mechanical properties of the gel, decrease enzyme leakage and increase the immobilization yields and the operational stability. The best results were achieved using as additives gelatin and silica gel. The immobilized glycosidases were used to increase the aroma in a model wine solution. The authors established that both free and immobilized enzymes led to a four-fold increase in the concentration of several of the more fragrant volatile compounds found in wine, particularly in Moscato wine.

$\mathrm{Su}$ et al. [111] immobilized $\beta$-glucosidase on alginate by combining cross-linking with entrapment and, again, cross-linking. After optimization of the immobilization conditions, an activity recovery of $\beta$-glucosidase of $46.0 \%$ was obtained. The authors investigated the properties of the immobilized $\beta$-glucosidase. The optimum $\mathrm{pH}$ remained unaltered, while the optimum temperature was $45^{\circ} \mathrm{C}$, which was $10^{\circ} \mathrm{C}$ lower than that of free enzyme. This particular feature can, however, be taken advantage of in tea beverage processing. Thus, the treatment with immobilized $\beta$-glucosidase can be carried out at a lower temperature than with the free enzymes, hence the high temperature, resulting in brownness of the tea infusion, can be avoided. Immobilization also resulted in an enhancement in the thermal stability. Moreover, the immobilized enzyme was more stable under extreme $\mathrm{pH}$ conditions. The $K_{\mathrm{m}}$ value for immobilized $\beta$-glucosidase was estimated to be $1.97 \times 10^{-3} \mathrm{~mol} / \mathrm{L}$, about 5 -fold lower than that of the free enzyme, which was ascribed to structural changes in the enzyme structure as an outcome of immobilization. The feasibility of using the immobilized enzyme as an aroma-enhancer of tea beverages was also assessed. The results showed that in tea beverages processed with immobilized $\beta$-glucosidase, the total amount of essential oil in green tea, oolong tea and black tea increased by $20.69 \%, \quad 10.30 \%$ and $6.79 \%$, respectively. Immobilization increased the storage stability of $\beta$-glucosidase, since $73.3 \%$ activity retention was observed after 42 days' storage at $4{ }^{\circ} \mathrm{C}$, whereas for 
the free enzyme, only 5.1\% activity retention was observed after 20 days' storage. Moreover, the immobilized enzyme displayed a residual activity of $93.6 \%$ after being repeatedly used 50 times.

Figueira et al. [112] screened various supports for the immobilization of a partially purified extract of $\beta$-glucosidase from Aspergillus sp. The immobilization in sol-gel and in Lentikats allowed the higher activity retention after immobilization and was thus further characterized. Immobilization did not alter the $\mathrm{pH} /$ activity profile, whereas the temperature/activity profile was improved when sol-gel support was assayed. Both thermal and $\mathrm{pH}$ stability were improved as a result of immobilization. An increase in the apparent $K_{\mathrm{m}}$ (Michaelis constant) was observed following immobilization, suggesting diffusion limitations.

Pectic enzymes have long been used in the beverage industry to increase juice yield and to clarify juices [113]. An example is pectinlyase (PL, EC 4.2.2.10), which has received growing attention for its potential application in the food processing industry, due to its ability to depolymerize pectins in a single enzyme process, doing away with the need to use pectinesterase (PE, EC 3.1.1.11), and polygalacturonase (PG, EC 3.2.1.15). The latter process releases methanol and leads to the formation of colloidal precipitates in the system, between the de-esterified pectin and the endogenous calcium ion [114,115].

Spagna et al. [106] used immobilized pectinlyase (PL, EC 4.2.2.10) for the depectinization of fruit juice. The authors performed the immobilization on three synthetic polymers: Eupergit C, Nylon 6 activated with glutaraldehyde and XAD7 activated with trichlorotriazine. Suitable activity results were obtained only with activated Nylon 6 and XAD7 (110 and $335 \mathrm{U} / \mathrm{g}$, respectively). An increase in stabilization was obtained by the rigidification of the enzyme structure through cross-linking with glutaraldehyde. The $\mathrm{pH}$ profile remains unaltered, however, the optimum temperature of the immobilized enzyme was higher $\left(8-10^{\circ} \mathrm{C}\right)$ than that of the free enzyme.

Alkorta et al. [116] immobilized the enzyme pectin lyase [PNL, poly(methoxygalacturonide) lyase; E.C. 4.2.2.10] from Penicillium italicurn by covalent binding to Nylon 6 in order to compare physical-chemical and kinetic properties of the free and immobilized enzymes. The authors evaluated the optimum conditions for the immobilization process, kinetic parameters and $\mathrm{pH}$ and temperature behavior of the enzyme. The $\mathrm{pH}$ activity curve of the immobilized enzyme shifted toward a low $\mathrm{pH}$ compared with that of the soluble one. Similarly, the immobilized PNL was more stable at lower $\mathrm{pH}$ values than the free enzyme. The immobilization caused a marked increase in both thermal and storage stability of the enzyme. No loss of activity was observed when the immobilized enzyme was used for 12 consecutive cycles of operation. The decrease in viscosity of pectin solutions processed with immobilized PNL was lower than that of solutions processed with free PNL. When fruit juices were used, however, the decrease in viscosity throughout processing was as marked as that observed when the free enzyme was used to clarify pectin solutions. Given the results obtained, the authors suggested that Nylon-immobilized PNL provided a promising tool for the clarification of fruit juices at $40{ }^{\circ} \mathrm{C}$ and an approximate $\mathrm{pH}$ of 3.0 . 


\section{Immobilized Carbohydrases in the Production of Prebiotics}

\subsection{Galactooligosaccharides}

Galactooligosaccharides (GOS) are an example of functional foods. GOS are prebiotic, because they are not digested by humans or other animals, and selectively increase the beneficial microflora of the intestine, leading to health benefits. GOS can be synthesized by highly specific glycosyltransferases, which use sugar donors containing a nucleoside phosphate or a lipid phosphate remaining group. However, these enzymes are barely available, are extremely expensive and require specific sugar nucleotides as substrates. Therefore, they are not used in realistic, cost-effective processes for GOS production [117]. Thus, GOS molecules are typically synthesized by the enzymatic activity of $\beta$-galactosidase on lactose in a reaction known as transgalactosylation. The composition of GOS produced from lactose by $\beta$-galactosidase usually has the structure $\mathrm{Gal}_{\mathrm{n}}$-Glc, where $n$ indicates the degree of polymerization (DP) and is typically within 1-5. The process is kinetically controlled and involves competition between hydrolysis and transgalactosylation. The former, which is thermodynamically favored and leads to the production of D-galactose and D-glucose, competes with the transferase activity, which leads to the production of the complex mixture of $\mathrm{Gal}_{\mathrm{n}}-\mathrm{Glc}$ saccharides. Knowledge of the time course of the reaction or of lactose conversion is needed to establish when the maximum yield of a given product is achieved. The process is quite complex, and the output clearly depends on the origin of the enzyme and on its properties [117,118]. Several models have been proposed to describe oligosaccharide synthesis and simultaneous lactose hydrolysis, ultimately pointing for the need of a high initial lactose concentration, viz. 40\% $w / v$ and above [6,119-122]. The recent findings of Vera and co-workers established that an increase in the initial lactose concentration only influences positively the maximum product yield, provided the lactose remains dissolved [6]. These authors also highlight the complex interaction between temperature and initial lactose concentration in the reaction of synthesis. Gosling and co-workers also produced insight on the phenomenon underlying the need for the highest possible lactose concentration to achieve high GOS levels [123]. Given the results obtained in their work, these authors suggested that such an outcome is due to increases in the reactions that lead to oligosaccharides instead of decreases in the competing reactions, which degrade oligosaccharides.

Gaur et al. [124] immobilized Aspergillus oryzae $\beta$-galactosidase by three different techniques: adsorption on Celite, covalent coupling to chitosan and aggregation by cross-linking (CLEAs). No significant changes in temperature and $\mathrm{pH}$ optima resulted from immobilization, however, an increase in $K_{\mathrm{m}}$ was observed, as compared to the free form. Immobilization on chitosan gave the maximum enzyme activity yield and oligosaccharide synthesis. Immobilization enhanced the thermal stability of both chitosan immobilized enzyme and CLEAs. When a 20\% (w/v) lactose solution was used as substrate, the chitosan-immobilized enzyme led to a maximum oligosaccharide yield, corresponding to $17.3 \%$ of the total sugar, whereas the use of the free enzyme only allowed an oligosaccharide yield corresponding to $10.0 \%$ of the total sugars, after $2 \mathrm{~h}$ of operation at $40{ }^{\circ} \mathrm{C}$. On the other hand, CLEAs proved instead effective in lactose hydrolysis, yielding 78\% monosaccharide after $12 \mathrm{~h}$ of operation. Galactooligosaccharides were continuously produced using lactose and $\beta$-galactosidase from Bullera singularis ATCC 24193 immobilized in Chitopearl BCW 3510 beads [125]. No activation or 
cross-linking agents were used before or after immobilization. The preparation was used directly for continuous reaction in a packed bed reactor, yielding 55\% $(w / w)$ oligosaccharides and a productivity of $4.4 \mathrm{~g} / \mathrm{L} \mathrm{h}$, from a $10 \%(w / v)$ lactose solution during a 15-day operation. Batch productivity was $6.5 \mathrm{~g}$ galactooligosaccharides $/ \mathrm{L} \mathrm{h}$ from a $0.3 \%(w / v)$ lactose solution.

Magnetic polysiloxane-polyvinyl alcohol proved to be an adequate support for the immobilization of Aspergillus oryzae $\beta$-galactosidase and its concomitant application on galactooligosaccharide production using lactose as substrate [121]. The support was easily recovered by applying a magnetic field, which contributed to achieving the retention of $84 \%$ of the initial enzyme activity after 10 reaction cycles. The galactooligosaccharides production was performed at temperatures varying from $30{ }^{\circ} \mathrm{C}$ to $60{ }^{\circ} \mathrm{C}$ and $\mathrm{pH}$ from 3.5 to 5.5, with either free or immobilized enzyme preparations, yet GOS production remained relatively unaltered despite such variations of operational condition. Magnetite particles obtained by coprecipitation of $\mathrm{Fe}^{2+}$ and $\mathrm{Fe}^{3+}$ and coated with polyaniline were activated with glutaraldehyde in order to covalently immobilize Aspergillus oryzaeß-galactosidase [126]. The methodology allowed for the immobilization of $2.04 \mathrm{mg}$ of enzyme per $\mathrm{g}$ of support, which the authors claimed to be the best of the values reported in the literature. This magnetic enzymatic derivative was able both to hydrolyze lactose into glucose and galactose and to produce tri- and tetra-galactosides from lactose by transgalactosylation, and, overall, its performance was akin to that of the free enzyme. Thus, for lactose concentrations up to $100 \mathrm{~g} / \mathrm{L}$, the specific activities of both forms were similar, but for higher lactose concentrations, the initial specific reaction rate of the immobilized enzyme was affected as lactose concentrations increased. GOS production by both forms of the enzyme was unaffected within 30 to $60{ }^{\circ} \mathrm{C}$. The immobilized biocatalyst was recycled 10 times, at $25{ }^{\circ} \mathrm{C}$ and using a $20 \%(w / v)$ lactose solution in each cycle. At the end of the final cycle, the activity of the immobilized biocatalyst was $85 \%$ of the initial value. Another magnetic type of support was used for the covalent immobilization of Kluyveromyces fragilis $\beta$-galactosidase [127]. The magnetic nanobeads were prepared from glycidyl methacrylate, ethylene glycol dimethacrylate and hydroxyethyl methacrylate, via emulsifier-free emulsion polymerization. Binding to the enzyme molecules was formed through the epoxy groups on the surface of the beads. The maximum amount of enzyme attached to the support was of $145.6 \mathrm{mg} / \mathrm{g}$, corresponding to an activity recovery of $72.6 \%$. The immobilized enzyme displayed high catalytic activity for GOS synthesis and produced a total of $2.240 \mathrm{~g}$ GOS per gram of immobilized enzyme during 10 consecutive batch reactions. After these cycles, the immobilized biocatalyst retained $81.5 \%$ of its original activity.

A novel method of enzyme immobilization using Aspergillus oryzae $\beta$-galactosidase involving polyethyleneimine-enzyme aggregate formation and growth of aggregates on individual fibrils of cotton cloth leading to multilayer immobilization of the enzyme was developed by Albayrak and Yang [128]. A large amount of enzyme was immobilized, $250 \mathrm{mg} / \mathrm{g}$ support, with about $90 \%-95 \%$ efficiency. A maximum galactooligosaccharides production of $25 \%-26 \%(w / w)$ was achieved at near $50 \%$ lactose conversion from $400 \mathrm{~g} / \mathrm{L}$ of lactose at $\mathrm{pH} 4.5$ and $40{ }^{\circ} \mathrm{C}$. Tri- and tetra-saccharides were the major types of galactooligosaccharides formed, accounting for about $70 \%$ and $25 \%$ of the total galactooligosaccharides produced in the reactions, respectively. A marked increase in the thermal stability of the immobilized enzyme was also observed, as compared to the free form. The half-life for the immobilized enzyme on cotton cloth was close to one year at $40^{\circ} \mathrm{C}$, but only 21 days at $50{ }^{\circ} \mathrm{C}$. The immobilized biocatalyst enabled the GOS production of $26 \%(w / w)$ of total sugars, from a feed lactose 
solution of $40 \%(w / v)$ lactose at $\mathrm{pH} 4.5$ and $40{ }^{\circ} \mathrm{C}$, at $50 \%$ lactose conversion. The production of GOS from lactose was also carried out using $\beta$-galactosidase from Aspergillus oryzae, immobilized on a low-pressure plasma-modified cellulose acetate [129]. The novel method developed for multilayer enzyme immobilization involved the formation of a polyethyleneimine (PEI)-enzyme aggregate and concomitant growth on a cellulose acetate membrane. An enzyme load of $9.97 \mathrm{~g} / \mathrm{m}^{2}$ membrane was immobilized with $66 \%$ efficiency. The half-life of the membrane immobilized enzyme was roughly one month at $30{ }^{\circ} \mathrm{C}$, although this decreased to 60 hours at $60{ }^{\circ} \mathrm{C}$. The maximum GOS production of $27 \%(w / w)$ was obtained at $70 \%$ lactose conversion from a $32 \%(w / v)$ lactose at $\mathrm{pH} 4.5$ and $60{ }^{\circ} \mathrm{C}$. GOS were mostly composed by trisaccharides, as these accounted for roughly $75 \%$ of the total GOS.

GOS production was also achieved using $\beta$-galactosidase from Talaromyces thermophilus CBS 236.58 immobilized onto Eupergit $\mathrm{C}$, both under batchwise and a continuous mode of operation, the latter in a packed-bed reactor [130]. Maximum yields of GOS of 12, 39 and $80 \mathrm{~g} / \mathrm{L}$ was obtained for initial lactose concentrations of $5 \%, 10 \%$ and $20 \%(w / v)$, respectively, for batch conversion experiments. Under continuous operation, a maximum GOS concentration of about $50 \mathrm{~g} / \mathrm{L}$ was obtained with a dilution rate of $0.375 \mathrm{~h}^{-1}$ in a packed-bed reactor, for an initial lactose concentration of $20 \%(w / v)$. The composition of the GOS mixture was also shown to be influenced by the mode of operation. Thus, when the continuous packed-bed was used, more trisaccharides and less disaccharides were formed, as compared to batch operation. Several other papers have been published, focused on the use of different reactor configurations for GOS production, using immobilized $\beta$-galactosidase. Thus, packed-bed reactors containing immobilized $\beta$-galactosidase from Aspergillus candidus adsorbed onto D113 resin and entrapped in calcium alginate [131], and Aspergillus oryzea immobilized on cotton cloth [132] displayed GOS productivities of 87 and $106 \mathrm{~g} / \mathrm{L} \mathrm{h}$, respectively. It has also been reported that an improved method developed by the latter authors for $\beta$-galactosidase immobilization in cotton cloth led to a productivity of $6000 \mathrm{~g} / \mathrm{L} \mathrm{h}$ [128]; GOS production in a continuous stirred tank reactor using $B$. circulans $\beta$-galactosidase immobilized in controlled pore silica gel. The yield and the productivity in GOS were 1.7- and 1.9-fold higher, respectively, when compared to those using free enzymes [133]. Nakkharat et al. [134] developed an ultrafiltration membrane reactor containing Talaromyces thermophilus $\beta$-galactosidase, which allowed for a 5.6-fold increase in GOS productivity, when compared with the free enzyme,

\subsection{Fructooligosaccharides}

Fructooligosaccharides (FOS) are also prebiotic substances, calorie-free and noncariogenic sweeteners. FOS stimulate the growth of bifidobacteria and have been claimed to contribute towards the prevention of colon cancer and to reduce cholesterol, phospholipid and triglyceride levels in serum. FOS consist of a mixture of fructose oligomers, typically with two or three fructose units bound to the $\beta-2,1$ position of sucrose, and they are mainly composed of 1-kestose $\left(\mathrm{GF}_{2}\right)$, 1-nystose $\left(\mathrm{GF}_{3}\right)$ and 1-fructofuranosyl-nystose $\left(\mathrm{GF}_{4}\right)$. They are found in several vegetables or natural foods, however, the FOS are produced commercially through enzymatic synthesis from sucrose by microbial enzymes with fructosyltransferase activity [135]. The definition of transfructosylation still involves some controversy. As summarized recently, while some authors classified this reaction as that catalyzed by $\beta$-fructofuranosidase or invertase, others classified transfructosylation as a $\beta$-d-fructosyltransferase 
reaction [136]. When the latter is considered, fructosyltransferase activity is observed at high sucrose concentrations, whereas at low sucrose concentration hydrolytic activity is predominant. Thus, an array of disproportionate reactions leads to the formation of FOS and glucose, as a by-product from the fructosyltransferase activity, while fructose and glucose are formed as result of the hydrolytic activity [137,138]. FOS are produced according to a chain reaction, where two molecules of sucrose produce one molecule of GF2 and one molecule of glucose. Two molecules of $\mathrm{GF}_{2}$ react to produce one molecule of $\mathrm{GF}_{3}$ and one molecule of sucrose. Two molecules of $\mathrm{GF}_{3}$ react, leading to one molecule of $\mathrm{GF}_{4}$ and one molecule of $\mathrm{GF}_{2}$. One molecule of $\mathrm{GF}_{3}$ is also hydrolyzed to $\mathrm{GF}_{2}$ and one molecule of fructose. A predictive model, which includes substrate and glucose and fructose inhibition, was developed and provided a nice fit to the experimental data for FOS production from sucrose using a fructosyltransferase from Rhodotorula sp. A Michaelis-Menten behavior was observed, with substrate inhibition at high sucrose concentrations (up to $70 \% \mathrm{w} / \mathrm{v}$ ) alongside with glucose competitive inhibition related to sucrose, $\mathrm{GF}_{2}$ and $\mathrm{GF}_{3}$ uptakes. Inhibition was also noticed at high fructose concentrations (over 50\%). Hydrolyzing activity over $\mathrm{GF}_{3}$ was also identified [134].

There are different techniques to immobilize enzymes or whole microbial cells to produce FOS. In particular, encapsulation of the cells and enzymes is widely used. Cell entrapment in calcium alginate has been quite favored. This particular approach was implemented by Ning et al. [139] for the entrapment of Xanthophyllomyces dendrorhous cells, because of the relative ease of cell separation from the fermentation broth and the strong tolerance to high concentrations of substrates and products. The cells were mixed with $2 \%$ sodium alginate solution, and the cell-alginate mixture was extruded dropwise through a needle into a $0.2 \mathrm{M} \mathrm{CaCl}_{2}$ solution. The resulting beads were kept in $\mathrm{CaCl}_{2}$ solution at $4{ }^{\circ} \mathrm{C}$ for $24 \mathrm{~h}$ before use. The FOS procution process anchored in the use of this immobilized biocatalyst allowed for a maximum FOS yield of $236 \mathrm{~g} / \mathrm{L}$ after $15 \mathrm{~h}$ of reaction. Aspergillus japonicus mycelia immobilized in calcium alginate beads were also used for the production FOS [140]. The mycelia of the strain were held in $1.5 \%$ glutaraldehyde solution at $4{ }^{\circ} \mathrm{C}$ for $24 \mathrm{~h}$ before entrapment with calcium alginate. FOS production was performed in a batch process in a 2-L bioreactor, and the optimum $\mathrm{pH}$ and temperature for synthesis were $5.0-5.6$ and $55{ }^{\circ} \mathrm{C}$, respectively. Maximum production was achieved using 5.75\% (cellular weight/volume) of mycelia and $65 \%$ sucrose solution $(w: v)$ for four hours of reaction, at which point $61.28 \%$ of the total FOS contained $30.56 \%, 26.45 \%$ and $4,27 \%$ of $\mathrm{GF}_{2}, \mathrm{GF}_{3}$, and $\mathrm{GF}_{4}$ respectively. The immobilized biocatalyst was used in 23 consecutive batches with no significant loss of activity, suggesting the potential for large scale applications. Aureobasidium pullulans was immobilized in calcium alginate beads and used for continuous production of fructooligosaccharides using a packed-bed reactor [141]. For the immobilization procedure, a cell suspension, containing 4\% $(v / v)$ dry cells, was mixed with 3\% $(w / v)$ sodium alginate solution at 1:2(v/v). The mixture was extruded through syringe needles into a $0.1 \mathrm{M}$ $\mathrm{CaCl}_{2}$ solution. The resulting beads were cured for $2 \mathrm{~h}$ and then hardened overnight at $4{ }^{\circ} \mathrm{C}$. Optimum operation conditions were achieved with $770 \mathrm{~g}$ sucrose/L, fed at $200 \mathrm{~L} / \mathrm{h}$ at $50{ }^{\circ} \mathrm{C}$, and allowed for a productivity of $180 \mathrm{~g}$ FOS $/ \mathrm{L}$ h. Moreover, the initial activity was maintained for about 100 days of operation in a $1.2 \mathrm{~m}^{3}$ reactor, so that a FOS content of $57 \%(w / w)$ in the effluent was obtained throughout this period. Aureobasidium pullulans cells were mixed with an alginate solution 3\% (w/v), and the mixture was extruded into a $1 \%(w / v) \mathrm{CaCl}_{2}$ solution to form small gel beads as hydrated-immobilized cells [142]. The immobilized cells were cured at room temperature for $2 \mathrm{~h}$ and 
then hardened overnight at $4{ }^{\circ} \mathrm{C}$. The beads were then placed at $-15{ }^{\circ} \mathrm{C}$ for $6-24 \mathrm{~h}$ to induce freeze-dehydration. The freeze-dehydration resulted in shrinkage of the beads as a result of water removal. As a result, the bead volume was reduced by $82 \%$ and the bead weight by $85 \%$. The dehydrated beads were successfully used for the production of FOS in a model reactor system.

Other techniques have been studied for enzyme and cell immobilization to produce FOS. A crude $\beta$-fructofuranosidase preparation from Aspergillus awamori NBRC4033 was covalently bound to chitosan by glutaraldehyde linkages and used for FOS synthesis from sucrose [143]. The obtained crude extract, after filtration and centrifugation, was directly used as an enzyme source in the immobilization process. This involves firstly the solubilization and activation of chitosan, respectively, with acetic acid and glutaraldehyde at $1 \%(v / v)$, followed by the covalent binding of the enzyme to the GA-activated chitosan at $\mathrm{pH}$ 5.0. In the conditions used, $88 \%$ of the crude extract was bound, and an activity recovery of $54 \%$ was reported. No significant changes were observed in the $\mathrm{pH}$ and temperature optima of the immobilized biocatalyst, as compared to the free form, yet both $\mathrm{pH}$ and thermal stability of the former were increased. Immobilization resulted in diffusion limitations, as reflected by a 1.3-fold increase in $K_{\mathrm{m}}$. Transfructosylation only occurred at high sucrose concentrations, from 133.35 to $231.94 \mathrm{~g} / \mathrm{L}$, while at lower sucrose concentrations, 51.2 to $74.29 \mathrm{~g} / \mathrm{L}$, hydrolysis took place. The maximum conversion yield of sucrose to FOS was 55\%, corresponding to $128 \mathrm{~g} / \mathrm{L}$ of FOS and to a calculated productivity of $18.53 \mathrm{~g} / \mathrm{h} / 100 \mathrm{~g}$. Kovaleva et al. [144] have shown that inulinase covalently immobilized on macroporous anion-exchange resin (AV-16-GS) had higher optimal temperature and $\mathrm{pH}$ stability than free inulinase. Commercial pectinase preparations with fructosyltransferase activity, Pectinex Ultra SP-L, have also been immobilized in Sepabeads EC-EP3 and EC-EP5 carriers and applied to the batch synthesis of fructooligosaccharides. A sufficiently high sucrose concentration, $630 \mathrm{~g} / \mathrm{L}$, was used to shift activity towards transfructosylation, in detriment of hydrolysis [145]. The reaction was faster using EC-EP5 carriers, possibly because of reduced diffusion limitations presented by this support, given its morphology. The FOS concentration reached a maximum value of $387 \mathrm{~g} / \mathrm{L}$ after $36 \mathrm{~h}\left(240 \mathrm{~g} / \mathrm{L} \mathrm{GF}_{2}, 144 \mathrm{~g} / \mathrm{L} \mathrm{GF}_{2}\right.$ and $\left.3 \mathrm{~g} / \mathrm{L} \mathrm{GF}_{4}\right)$, which corresponds to $61.5 \%(w / w)$ of the total carbohydrates in the mixture. The features of these immobilized biocatalysts are very attractive for their application in batch and fixed-bed bioreactors. The fructosyltransferase produced by Rhodotorula sp. was immobilized in an inorganic support consisting of a niobium and graphite alloy [146]. The immobilization of the enzyme was by ionic binding to the surface of the particles, since the support is a charged and compact solid, with negligible porosity. The immobilized fructosyltransferase in niobium allowed for FOS yields of around $46 \%$ from sucrose concentrations of $50 \%$ and $70 \%(w / v)$, after $96 \mathrm{~h}$ of synthesis. $\mathrm{GF}_{2}$ was the predominant fructan produced, with $\mathrm{GF}_{3}$ and $\mathrm{GF}_{4}$ present in smaller amounts. A predictive model of FOS production was developed, which provided a close fit to experimental data.

\section{Other Immobilized Carbohydrases}

\subsection{Dairy Products}

The enzyme $\beta$-galactosidase (3.2.1.23) is classified as a hydrolase, with transferase capacity for galactosyl groups, catalyzing the hydrolysis of the terminal residue $\beta$-galactopyranosyl from lactose 
(Gal $\beta$ 1-4Glc) to form an isomolecular mixture of glucose and galactose [20]. $\beta$-Galactosidase is an important enzyme in the food industry and has found significant applications in enhancing sweetness, solubility, flavor and digestibility of dairy products [147].

Guidini et al. [148] studied the immobilization process of Aspergillus oryzae $\beta$-galactosidase using the ionic exchange resin Duolite A568 as a carrier for lactose hydrolysis. The immobilization process by ionic binding was studied through a central composite design (CCD). The simultaneous influences of the enzyme concentration and $\mathrm{pH}$ on the immobilization medium were analyzed by the authors. The results showed that the retention of enzymatic activity during the immobilization process was strongly dependant on those variables, being maximized at $\mathrm{pH} 4.5$ and an enzyme concentration of $16 \mathrm{~g} / \mathrm{L}$. The immobilized enzyme obtained under the previous conditions was subjected to a cross-linking process with glutaraldehyde, and the conditions that maximized the activity consisted of a glutaraldehyde concentration of $3.83 \mathrm{~g} / \mathrm{L}$ and a cross-linking time of $1.87 \mathrm{~h}$. The glutaraldehyde cross-linking increased the initial activity, retaining $90 \%$ of its initial activity. The authors related that the enzyme was very stable on $\mathrm{pH}$ ranges of 3.5-8.0, being appropriate for application in products with low $\mathrm{pH}$ values, such as acid whey, since the enzyme activity was maximized at $\mathrm{pH} 4.5$.

Pessela et al. [149] performed the immobilization of $\beta$-galactosidase from Thermus sp. T2 via ionic adsorption onto two different supports: a new anionic exchanger resin, based on the coating of Sepabeads internal surfaces with polyethylenimine (PEI) polymers (Mw 25,000), and traditional DEAE-agarose. The adsorption strength was much higher in the case of PEI-Sepabeads than in DEAE-supports at both $\mathrm{pH} 5$ and 7. Less than 5\% of enzyme was eluted from PEI-support, while more than $70 \%$ protein was eluted from DEAE-agarose at $\mathrm{pH} 7$ and $0.4 \mathrm{M} \mathrm{NaCl}$. The PEI-derivatives remained almost fully active at $\mathrm{pH} 5$ and 7 after several weeks of incubation at $50{ }^{\circ} \mathrm{C}$, and their thermal stability was enhanced as compared to that of the free form. In particular, the derivative was used to perform the hydrolysis of $5 \%$ lactose solution for $50 \mathrm{~h}$ at $\mathrm{pH} 7$ and $50{ }^{\circ} \mathrm{C}$, with no noticeable shift in the pattern of the reaction. Moreover, it was established that after such a cycle, the derivative could be fully removed from the support and the latter re-loaded. Given these features, the authors suggested the immobilized biocatalyst presents a promising candidate for industrial use as a biocatalyst in the hydrolysis of lactose in different dairy products and could be coupled with the antimicrobial treatment usually performed. Moreover, Pessela and co-workers were able to establish that covalent immobilization of $\beta$-galactosidase from Thermus sp. T2 on boronate-epoxy-Sepabeads and on chelate-epoxy-Sepabeads reduced significantly the inhibition by glucose (non-competitive) and by galactose (competitive) observed for the free form [150]. At the same time, the $K_{\mathrm{m}}$ for lactose only increased by two-fold as an outcome of immobilization. The authors associated these outcomes to small modifications in the active center conformation that may have occurred after immobilization onto the heterofunctional epoxy-Sepabeads, which led to a more marked decrease in the affinity of the enzyme to the inhibitor than that to the substrate. Thus, using either immobilized enzyme preparation for the hydrolysis of a $5 \%(w / v)$ lactose solution, the reaction proceeded up to a hydrolysis yield over $99 \%$, whereas for the free enzyme, only $85 \%$ hydrolysis could be achieved.

A rather similar observation was reported by Mateo and co-workers when immobilizing $\beta$-galactosidase from Kluyveromyces lactis in agarose-glyoxyl, glutaraldehyde-agarose and glutaraldehyde-Eupergit $C$ supports [151]. Yet, in these supports, only the non-competitive inhibition by glucose was significantly reduced, while both the affinity of the enzyme to the competitive inhibitor 
(galactose) and to the substrate (lactose) remained unaltered, as compared to the free form, possibly due to steric hindrances to the access of glucose to the binding site. Somehow, curiously, the immobilization to an Eupergit-boronate derivative led to no changes in the non-competitive inhibitor. This was considered the result of binding taking place through the sugar chains, thus leaving the inhibition site exposed. Actually, no modifications were noticed regarding the affinity of the enzyme to lactose and galactose as a result of immobilization. Moreover, the glyoxyl-agarose derivative was for 20 reactions with a marginal decrease enzyme activity and allowing for almost full hydrolysis of a $5 \%(w / v)$ lactose solution at the end of the final batch.

Tanriseven and Dogan [152] immobilized $\beta$-galactosidase from Aspergillus oryzae in fibers composed of alginate and gelatin cross-linked with glutaraldehyde to avoid leaking out of the enzyme. The immobilization yield was of $56 \%$, and the activity of the immobilized biocatalyst remained stable for 35 days. The optimum $\mathrm{pH}$ and temperature were not affected by immobilization and remained at 4.5 and $50{ }^{\circ} \mathrm{C}$, respectively. Yet, higher activity retention at extreme $\mathrm{pH}$ and temperature was observed for immobilized $\beta$-galactosidase. A 1.2-fold increase in $K_{\mathrm{m}}$ as a result of immobilization suggests a typical diffusion limitations increase, and the maximum specific reaction rate decreased almost by half, suggesting structural changes in the enzyme. $\beta$-galactosidase was immobilized by adsorption on a mixed-matrix membrane containing zirconium dioxide [153]. Up to $1.6 \mathrm{~g} \beta$-galactosidase could be absorbed per $\mathrm{m}^{2}$ of membrane. However, maximal activity was achieved at an enzyme load of around $0.5 \mathrm{~g} / \mathrm{m}^{2}$. Although the optimum $\mathrm{pH}$ for activity was shifted from 6.5 to 7.0 , due to immobilization, no significant change was observed in the optimum temperature. Activity retention was, however, more effective at lower temperatures, within the range tested $\left(5\right.$ to $\left.40{ }^{\circ} \mathrm{C}\right)$. Moreover, an eight-fold increase in the apparent $K_{\mathrm{m}}$ was observed after immobilization, although $V_{\max }$ remained unaltered. The authors suggest the feasibility of the immobilized biocatalysts for application to GOS synthesis.

\subsection{Isomaltulose Production}

Isomaltulose is a monosaccharide that presents remarkable applications in the food industry. This sugar is an interesting substitute for sucrose, considering that it is approximately $50 \%$ as sweet as sucrose [154], it is non-carcinogenic [155] and it has a low glycemic index [156]. In addition, isomaltulose can be converted into sugar alcohol, Isomalt ${ }^{\circledR}$, which has other useful properties for foods. Isomaltulose can be industrially obtained by transglycosylation, catalyzed by the intracellular glucosyltransferase produced by some bacteria strains.

There are several works on the immobilization of bacterial cells to produce isomaltulose. Yet, considering the advantages of the use of enzyme extracts, mainly the reduced level of microbial contamination of the product, the immobilization of the extracted glucosyltransferase can be attractive if an efficient immobilization method is developed.

In the work of Kawaguti and Sato [8], isomaltulose production was studied in a repeated-batch process using immobilized glucosyltransferase. The highest conversion rate of sucrose into isomaltulose was obtained in the first batches, being 43.1\%. It was observed that after the first batch, the conversion rates decreased quickly, and in the second batch, an isomaltulose production rate of $7.3 \%$ was obtained. The same research group reported the immobilization of glucosyltransferase extracted from the cells of Erwinia sp. onto Celite 545. The authors observed that the optimal 
conditions for immobilization were at $\mathrm{pH} 4.0$ and $170 \mathrm{U}$ of glucosyltransferase/g of Celite 545 . Using these conditions, more than $60 \%$ conversion of sucrose into isomaltulose could be obtained. The enzyme was also immobilized in microcapsules of low-methoxyl pectin and fat (butter and oleic acid). The non-lyophilized microcapsules of pectin containing the glucosyltransferase and fat converted $30 \%$ of sucrose into isomaltulose in the first batch [157].

\section{Conclusions}

As reported in this review, different types of carbohydrases have huge potential for application in the food industry. However, because of the cost for the application of these biocatalysts, many studies should focus on the development of cheap and efficient immobilization methods. Considering that the application is for the food industry, different parameters are considered. For example, most of the steps where these enzymes are applied are in an aqueous solution. Thus, if the enzyme is weakly adsorbed into the support, it can easily desorb from the matrix. On the other hand, if adsorption/desorption occurs in differentiated and well-controlled environments, carrier reuse, once enzymatic activity is exhausted, is feasible. Unwanted enzyme desorption can be avoided with the covalent bonding of the enzyme into the support. But, extreme caution should be taken considering that this technique needs extremely toxic reagents, such as glutaraldehyde. Significant advances have been made in this field with the introduction of pre-activated hetero-functional supports, which somehow simplify the methodology and, moreover, allow the site-directed rigidification of the enzyme. The feasibility of the method requires, nevertheless, knowledge of the residues of the catalytic site to prevent drawbacks similar to those in random binding. Moreover, extreme rigidification may be a drawback for enzymes displaying large conformational changes during catalysis. Finally, the entrapment of the enzyme into some gels or synthetic polymers has to be very well studied, taking into consideration the porosity of the matrix and the size of the enzyme (molecular weight) and of the substrate/product. However, if adequately identified and implemented, the immobilization methods can enhance enzyme stability, activity and selectivity. In the design of the immobilization methods, it should be brought to mind that the selection of the immobilization method must take in to consideration the specific nature of the reaction to be catalyzed and the reactor configuration and not only consider the highest stabilization and activity of the enzyme. This is of relevance, since successful industrial applications of the immobilized biocatalysts require not only that it is stable and active, but also that it has low cost, can undergo repeated re-use and is compatible with the intended set-up. Growing knowledge on the 3D structure of enzymes and in their surface composition provides a powerful tool for a more rational design of immobilization, but this has to be combined with insight on the physical and chemical properties of the support. The application of molecular simulation methods has been contributing to the rational development of immobilization strategies, but this approach is still limited. Further experimental evidence on the structure of the enzyme after immobilization is still required to better understand the outcome of immobilization and, thus, help the development of suitable models. Given the large number of enzymes with interest for the food and feed industry, along with that of promising available supports, and the vast resources required for their molecular characterization and development of predictive models, it can be foreseen that the random, trial and error approach will still be used in the near future, at least in a screening role. The current high throughput platforms currently 
available allow for the evaluation of a large number of variables in a timely, cost-effective manner. A major challenge is also the development of tailor-made carriers displaying tunable binding, geometric and mechanical properties, so that they can be used in different reactor configurations and, so, allow a more efficient and cost effective continuous use or reuse of the biocatalysts. The successful accomplishment of such an endeavor is clearly a multidisciplinary task, since it involves computational modeling of materials, life science and computational scientists, alongside with biochemical engineers

\section{Acknowledgments}

The authors are grateful to Fundação de Amparo à Pesquisa do Estado de São Paulo (FAPESP) (Processes numbers 2009/09224-3 and 2011/12394-8), Conselho Nacional de Desenvolvimento Científico (CNPq) and Coordenação de Aperfeiçoamento de Pessoal de Nível Superior (CAPES) (Brazil) for their financial support. We would like to thank Pedro Carlos de Barros Fernandes, one of the co-authors, who, with his experience, contributed immensely to the preparation of this article.

\section{Conflict of Interest}

The authors declare no conflict of interest.

\section{References}

1. Simpson, B.K.; Rui, X.; Klomklao, S. Enzymes in Food Processing. In Food Biochemistry and Food Processing, 2nd ed.; Simpson, B.K., Ed.; Wiley-Blackwell: Oxford, UK, 2012; pp. 181-206.

2. Jana, M.; Maity, C.; Samanta, S.; Pati, B.R.; Islam, S.S.; Mohapatra, P.K.D.; Mondal, K.C. Salt-independent thermophilic $\alpha$-amylase from Bacillus megaterium VUMB109: An efficacy testing for preparation of maltooligosaccharides. Ind. Crop. Prod. 2013, 41, 386-391.

3. Akgöl, S.; Kaçar, Y.; Denizli, A.; Arıca, M.Y. Hydrolysis of sucrose by invertase immobilized onto novel magnetic polyvinylalcohol microspheres. Food Chem. 2001, 74, 281-288.

4. Nakamura, T.; Ogata, Y.; Shitara, A.; Nakamura, A.; Ohta, K. Continuous production of fructose syrups from inulin by immobilized inulinase from Aspergillus niger mutant 817. J. Ferm. Bioeng. 1995, 80, 164-169.

5. Vasiljevic, T.; Jelen, P. Production of $\beta$-galactosidase for lactose hydrolysis in milk and dairy products using thermophilic lactic acid bacteria. Innov. Food Sci. Emerg. 2001, 2, 75-85.

6. Vera, C.; Guerrero, C.; Conejeros, R.; Illanes, A. Synthesis of galacto-oligosaccharides by $\beta$-galactosidase from Aspergillus oryzae using partially dissolved and supersaturated solution of lactose. Enzyme Microb. Technol. 2012, 50, 188-194.

7. Krisch, J.; Bencsik, O.; Papp, T.; Vágvölgyi, C.; Takó, M. Characterization of a $\beta$-glucosidase with transgalactosylation capacity from the zygomycete Rhizomucor miehei. Bioresour. Technol. 2012, 114, 555-560.

8. Kawaguti, H.Y.; Sato, H.H. Palatinose production by free and Ca-alginate gel immobilized cells of Erwinia sp. Biochem. Eng. J. 2007, 36, 202-208.

9. Tufvesson, P.; Lima-Ramos, J.; Nordblad, M.; Woodley, J.M. Guidelines and cost analysis for catalyst production in biocatalytic processes. Org. Process Res. Dev. 2010, 15, 266-274. 
10. Dodge, T. Production of Industrial Enzymes. In Enzymes in Food Technology, 2nd ed.; Amauri, A.B., Ed.; Wiley-Blackwell: Hoboken, NJ, USA, 2009; pp. 44-58.

11. Wen, F.; McLachlan, M.; Zhao, H. Directed Evolution: Novel and Improved Enzymes. In Wiley Encyclopedia of Chemical Biology; John Wiley \& Sons, Inc.: Hoboken, NJ, USA, 2008; pp.1-10.

12. Martins, D.A.B.; Prado, H.F.A.; Leite, R.S.R.; Ferreira, H.; Moretti, M.M.S.; Silva, R.; Gomes, E. Agroindustrial wastes as substrates for microbial enzymes production and source of sugar for bioethanol production. In Integrated Waste Management; Kumar, S., Ed.; In Tech: Rijeka, Croatia, 2011; Volume 2, pp. 319-361.

13. Hanefeld, U.; Gardossi, L.; Magner, E. Understanding enzyme immobilisation. Chem. Soc. Rev. 2009, 38, 453-468.

14. Torres-Salas, P.; del Monte-Martinez, A.; Cutiño-Avila, B.; Rodriguez-Colinas, B.; Alcalde, M.; Ballesteros, A.O.; Plou, F.J. Immobilized biocatalysts: Novel approaches and tools for binding enzymes to supports. Adv. Mater. 2011, 23, 5275-5282.

15. Kahraman, M.V.; Bayramoğlu, G.; Kayaman-Apohan, N.; Güngör, A. $\alpha$-Amylase immobilization on functionalized glass beads by covalent attachment. Food Chem. 2007, 104, 1385-1392.

16. Silva, R.N.; Asquieri, E.R.; Fernandes, K.F. Immobilization of Aspergillus niger glucoamylase onto a polyaniline polymer. Process Biochem. 2005, 40, 1155-1159.

17. Zhang, L.; Zhu, X.; Zheng, S.; Sun, H. Photochemical preparation of magnetic chitosan beads for immobilization of pullulanase. Biochem. Eng. J. 2009, 46, 83-87.

18. Guiraud, J.; Demeulle, S.; Galzy, P. Inulin hydrolysis by the Debaryomyces phaffii inulinase immobilized on DEAE cellulose. Biotechnol. Lett. 1981, 3, 683-688.

19. Tanriseven, A.; Doğan, Ş. Immobilization of invertase within calcium alginate gel capsules. Process Biochem. 2001, 36, 1081-1083.

20. Neri, D.F.M.; Balcão, V.M.; Cunha, M.G.C.; Carvalho, L.B., Jr.; Teixeira, J.A. Immobilization of $\beta$-galactosidase from Kluyveromyces lactis onto a polysiloxane-polyvinyl alcohol magnetic (mPOS-PVA) composite for lactose hydrolysis. Catal. Commun. 2008, 9, 2334-2339.

21. González-Pombo, P.; Fariña, L.; Carrau, F.; Batista-Viera, F.; Brena, B.M. A novel extracellular $\beta$-glucosidase from Issatchenkia terricola: Isolation, immobilization and application for aroma enhancement of white Muscat wine. Process Biochem. 2011, 46, 385-389.

22. Li, T.; Wang, N.; Li, S.; Zhao, Q.; Guo, M.; Zhang, C. Optimization of covalent immobilization of pectinase on sodium alginate support. Biotechnol. Lett. 2007, 29, 1413-1416.

23. Tanriseven, A.; Aslan, Y. Immobilization of Pectinex Ultra SP-L to produce fructooligosaccharides. Enzyme Microb. Technol. 2005, 36, 550-554.

24. Mateo, C.; Palomo, J.M.; Fernandez-Lorente, G.; Guisan, J.M.; Fernandez-Lafuente, R. Improvement of enzyme activity, stability and selectivity via immobilization techniques. Enzyme Microb. Technol. 2007, 40, 1451-1463.

25. Garcia-Galan, C.; Berenguer-Murcia, Á.; Fernandez-Lafuente, R.; Rodrigues, R.C. Potential of different enzyme immobilization strategies to improve enzyme performance. Adv. Synth. Catal. 2011, 353, 2885-2904.

26. Rodrigues, R.C.; Ortiz, C.; Berenguer-Murcia, A.; Torres, R.; Fernandez-Lafuente, R. Modifying enzyme activity and selectivity by immobilization. Chem. Soc. Rev. 2013, doi:10.1039/C2CS35231A. 
27. Iyer, P.V.; Ananthanarayan, L. Enzyme stability and stabilization-Aqueous and non-aqueous environment. Process Biochem. 2008, 43, 1019-1032.

28. Bes, M.T.; Carlos-Moreno, C.; Guisan, J.M.; Fernandez-Lafuente, R.; Gomez-Moreno, C. Selective oxidation: Stabilisation by multipoint attachment of ferredoxin NADP $^{+}$reductase, an interesting cofactor recycling enzyme. J. Mol. Catal. A Chem. 1995, 98, 161-169.

29. Sheldon, R.A. Enzyme immobilization: The quest for optimum performance. Adv. Synth. Catal. 2007, 349, 1289-1307.

30. Singh, A.K.; Flounders, A.W.; Volponi, J.V.; Ashley, C.S.; Wally, K.; Schoeniger, J.S. Development of sensors for direct detection of organophosphates Part I immobilization characterization and stabilization of acetylcholinesterase and organophosphate hydrolase on silica supports. Biosens. Bioelectron. 1999, 14, 703-713.

31. Takahashi, H.; Li, B.; Sasaki, T.; Miyazaki, C.; Kajino, T.; Inagaki, S. Catalytic activity in organic solvents and stability of immobilized enzymes depend on the pore size and surface characteristics of mesoporous silica. Chem. Mater. 2000, 12, 3301-3305.

32. Hsu, A.-F.; Foglia, T.A.; Shen, S. Immobilization of Pseudomonas cepacia lipase in a phyllosilicate sol-gel matrix: Effectiveness as a biocatalyst. Biotechnol. Appl. Biochem. 2000, 31, 179-183.

33. Betancor, L.; Fuentes, M.; Dellamora-Ortiz, G.; López-Gallego, F.; Hidalgo, A.; Alonso-Morales, N.; Mateo, C.; Guisán, J.M.; Fernández-Lafuente, R. Dextran aldehyde coating of glucose oxidase immobilized on magnetic nanoparticles prevents its inactivation by gas bubbles. J. Mol. Catal. B Enzym. 2005, 32, 97-101.

34. Brady, D.; Jordaan, J. Advances in enzyme immobilisation. Biotechnol. Lett. 2009, 31, 1639-1650.

35. Fernandez-Lafuente, R. Stabilization of multimeric enzymes: Strategies to prevent subunit dissociation. Enzyme Microb. Technol. 2009, 45, 405-418.

36. Dib, I.; Nidetzky, B. The stabilizing effects of immobilization in D-amino acid oxidase from Trigonopsis variabilis. BMC Biotechnol. 2008, 8, 1-11.

37. Bolivar, J.M.; Mateo, C.; Grazu, V.; Carrascosa, A.V.; Pessela, B.C.; Guisan, J.M. Heterofunctional supports for the one-step purification, immobilization and stabilization of large multimeric enzymes: Amino-glyoxyl versus amino-epoxy supports. Process Biochem. 2010, 45, $1692-1698$.

38. Da Silva, V.; Contesini, F.; de Oliveira Carvalho, P. Enantioselective behavior of lipases from Aspergillus niger immobilized in different supports. J. Ind. Microbiol. Biotechnol. 2009, 36, 949-954.

39. Gómez de Segura, A.; Alcalde, M.; J. Plou, F.; Remaud-simeon, M.; Monsan, P.; Ballesteros, A. Encapsulation in lentikats of dextransucrase from leuconostoc mesenteroides nrrl b-1299, and its effect on product selectivity. Biocatal. Biotransform. 2003, 21, 325-331.

40. Guidini, C.Z.; Fischer, J.; Resende, M.M.; Cardoso, V.L.; Ribeiro, E.J. $\beta$-Galactosidase of Aspergillus oryzae immobilized in an ion exchange resin combining the ionic-binding and crosslinking methods: Kinetics and stability during the hydrolysis of lactose. J. Mol. Catal. B Enzym. 2011, 71, 139-145.

41. Ray, R.R.; Jana, S.C.; Nanda, G. Biochemical approaches of increasing thermostability of $\beta$-amylase from Bacillus megaterium B6. FEBS Lett. 1994, 356, 30-32. 
42. Mateo, C.; Fernández-Lorente, G.; Abian, O.; Fernández-Lafuente, R.; Guisán, J.M. Multifunctional epoxy supports: A new tool to improve the covalent immobilization of proteins. The promotion of physical adsorptions of proteins on the supports before their covalent linkage. Biomacromolecules 2000, 1, 739-745.

43. Mateo, C.; Pessela, B.C.; Grazu, V.; López-Gallego, F.; Torres, R.; Fuentes, M.; Hidalgo, A.; Palomo, J.M.; Betancor, L.; Fernández-Lorente, G.; et al. Immobilization and stabilization of proteins by multipoint covalent attachment on novel amino-epoxy-sepabeads ${ }^{\circledR}$. 2006, 22, 153-162.

44. Basso, A.; Spizzo, P.; Ferrario, V.; Knapic, L.; Savko, N.; Braiuca, P.; Ebert, C.; Ricca, E.; Calabrò, V.; Gardossi, L. Endo- and exo-inulinases: Enzyme-substrate interaction and rational immobilization. Biotechnol. Prog. 2010, 26, 397-405.

45. Bolivar, J.M.; Nidetzky, B. Positively charged mini-protein zbasic2 as a highly efficient silica binding module: Opportunities for enzyme immobilization on unmodified silica supports. Langmuir 2012, 28, 10040-10049.

46. Gopinath, S.; Sugunan, S. Leaching studies over immobilized a-amylase. importance of the nature of enzyme attachment. React. Kinet. Catal. Lett. 2004, 83, 79-83.

47. Ivanov, A.E.; Schneider, M.P. Methods for the immobilization of lipases and their use for ester synthesis. J. Mol. Catal. B Enzym. 1997, 3, 303-309.

48. Brena, B.M.; Batista-Viera, F. Immobilization of Enzymes. In Methods in Biotechnology. Immobilization of Enzymes and Cells; Guisan, M.J., Ed.; Humana Press Inc.: Totowa, NJ, USA, 2006; pp. 15-30.

49. Cao, L.; Schmid, R.D. Carrier-bound Immobilized Enzymes: Principles, Application and Design. Wiley-VCH Verlag GmbH \& Co. KGaA, Weinheim, Germany, 2006.

50. Torres, R.; Mateo, C.; Fernández-Lorente, G.; Ortiz, C.; Fuentes, M.; Palomo, J.M.; Guisan, J.M.; Fernández-Lafuente, R. A novel heterofunctional epoxy-amino sepabeads for a new enzyme immobilization protocol: Immobilization-stabilization of $\beta$-galactosidase from Aspergillus oryzae. Biotechnol. Prog. 2003, 19, 1056-1060.

51. Hannibal-Friedrich, O.; Chun, M.; Sernetz, M. Immobilization of beta-galactosidase, albumin, and gamma-globulin on epoxy-activated acrylic beads. Biotechnol. Bioeng. 1980, 22, $157-175$.

52. Katchalski-Katzir, E.; Kraemer, D.M. Eupergit ${ }^{\circledR}$ C, a carrier for immobilization of enzymes of industrial potential. J. Mol. Catal. B Enzym. 2000, 10, 157-176.

53. Mateo, C.; Grazú, V.; Pessela, B.C.; Montes, T.; Palomo, J.M.; Torres, R.; López-Gallego, F.; Fernández-Lafuente, R.; Guisán, J.M. Advances in the design of new epoxy supports for enzyme immobilization-stabilization. Biochem. Soc. Trans. 2007, 35, 1593-1601.

54. Mateo, C.; Abian, O.; Fernández-Lorente, G.; Pedroche, J.; Fernández-Lafuente, R.; Guisan, J.M.; Tam, A.; Daminati, M. Epoxy Sepabeads: A novel epoxy support for stabilization of industrial enzymes via very intense multipoint covalent attachment. Biotechnol. Prog. 2002, $18,629-634$.

55. Grazú, V.; Abian, O.; Mateo, C.; Batista-Viera, F.; Fernández-Lafuente, R.; Guisán, J.M. Novel bifunctional epoxy/thiol-reactive support to immobilize thiol containing proteins by the epoxy chemistry. Biomacromolecules 2003, 4, 1495-1501. 
56. Abian, O.; Fernández-Lafuente, R.; García, J.L.; González García, R.; Grazú, V.; Guisán, J.M.; Hermoso, J.A. Stabilization of penicillin G acylase from Escherichia coli: Site-directed mutagenesis of the protein surface to increase multipoint covalent attachment. Appl. Environ. Microb. 2004, 70, 1249-1251.

57. Bolivar, J.M.; López-Gallego, F.; Godoy, C.; Rodrigues, D.S.; Rodrigues, R.C.; Batalla, P.; Rocha-Martín, J.; Mateo, C.; Giordano, R.L.C.; Guisán, J.M. The presence of thiolated compounds allows the immobilization of enzymes on glyoxyl agarose at mild $\mathrm{pH}$ values: New strategies of stabilization by multipoint covalent attachment. Enzyme Microb. Technol. 2009, 45, 477-483.

58. Godoy, C.A.; Rivas, B.; Grazú, V.; Montes, T.; Guisán, J.M.; López-Gallego, F. Glyoxyl-disulfide agarose: A tailor-made support for site-directed rigidification of proteins. Biomacromolecules 2011, 12, 1800-1809.

59. Hernandez, K.; Fernandez-Lafuente, R. Control of protein immobilization: Coupling immobilization and site-directed mutagenesis to improve biocatalyst or biosensor performance. Enzyme Microb. Technol. 2011, 48, 107-122.

60. Bernardino, S.; Estrela, N.; Ochoa-Mendes, V.; Fernandes, P.; Fonseca, L. Optimization in the immobilization of penicillin $\mathrm{G}$ acylase by entrapment in xerogel particles with magnetic properties. J. Sol-Gel Sci. Technol. 2011, 58, 545-556.

61. Pierre, A.C. The sol-gel encapsulation of enzymes. Biocatal. Biotransform. 2004, 22, 145-170.

62. Shah, S.; Sharma, A.; Gupta, M.N. Preparation of cross-linked enzyme aggregates by using bovine serum albumin as a proteic feeder. Anal. Biochem. 2006, 351, 207-213.

63. Dong, T.; Zhao, L.; Huang, Y.; Tan, X. Preparation of cross-linked aggregates of aminoacylase from Aspergillus melleus by using bovine serum albumin as an inert additive. Bioresour. Technol. 2010, 101, 6569-6571.

64. Cabana, H.; Jones, J.P.; Agathos, S.N. Preparation and characterization of cross-linked laccase aggregates and their application to the elimination of endocrine disrupting chemicals. J. Biotechnol. 2007, 132, 23-31.

65. López-Gallego, F.; Betancor, L.; Hidalgo, A.; Alonso, N.; Fernández-Lafuente, R.; Guisán, J.M. Co-aggregation of enzymes and polyethyleneimine: A simple method to prepare stable and immobilized derivatives of glutaryl acylase. Biomacromolecules 2005, 6, 1839-1842.

66. Wilson, L.; Illanes, A.; Abián, O.; Pessela, B.C.C.; Fernández-Lafuente, R.; Guisán, J.M. Co-aggregation of penicillin $\mathrm{G}$ acylase and polyionic polymers: An easy methodology to prepare enzyme biocatalysts stable in organic media. Biomacromolecules 2004, 5, 852-857.

67. Wilson, L.; Illanes, A.; Abián, O.; Fernández-Lafuente, R.; Guisan, J.M. Encapsulation of very soft cross-linked enzyme aggregates (CLEAs) into very rigid LentiKats. FAL Agric. Res. 2002, 241, 121-125.

68. Wilson, L.; Illanes, A.; Pessela, B.C.; Abian, O.; Fernández-Lafuente, R.; Guisán, J.M. Encapsulation of crosslinked penicillin $\mathrm{G}$ acylase aggregates in lentikats: Evaluation of a novel biocatalyst in organic media. Biotechnol. Bioeng. 2004, 86, 558-562.

69. Kim, J.; Lee, J.; Na, H.B.; Kim, B.C.; Youn, J.K.; Kwak, J.H.; Moon, K.; Lee, E.; Kim, J.; Park, J.; et al. A Magnetically separable, highly stable enzyme system based on nanocomposites of enzymes and magnetic nanoparticles shipped in hierarchically ordered, mesocellular, mesoporous silica. Small 2005, 1, 1203-1207. 
70. Hobbs, L. Sweeteners from Starch: Production, Properties and Uses. In Starch, 3rd ed.; James, B., Roy, W., Eds.; Academic Press: San Diego, CA, USA, 2009; pp. 797-832.

71. Roy, I.; Gupta, M.N. Hydrolysis of starch by a mixture of glucoamylase and pullulanase entrapped individually in calcium alginate beads. Enzyme Microb. Technol. 2004, 34, 26-32.

72. Al-Mayah, A.M.R. Simulation of enzyme catalysis in calcium alginate beads. Enzyme Res. 2012, doi:10.1155/2012/459190.

73. Ivanova, V.; Dobreva, E.; Legoy, M.D. Characteristics of immobilized thermostable amylases from two Bacillus licheniformis strains. Acta Biotechnol. 1998, 18, 339-351.

74. Shewale, S.D.; Pandit, A.B. Hydrolysis of soluble starch using Bacillus licheniformis $\alpha$-amylase immobilized on superporous CELBEADS. Carbohydr. Res. 2007, 342, 997-1008.

75. Singh, V.; Kumar, P. Carboxymethyl tamarind gum-silica nanohybrids for effective immobilization of amylase. J. Mol. Catal. B Enzym. 2011, 70, 67-73.

76. Tüzmen, N.; Kalburcu, T.; Denizli, A. A-amylase immobilization onto dye attached magnetic beads: Optimization and characterization. J. Mol. Catal. B Enzym. 2012, 78, 16-23.

77. Talekar, S.; Chavare, S. Optimization of immobilization of $\alpha$-amylase in alginate gel and its comparative biochemical studies with free $\alpha$-amylase. Rec. Res. Sci. Technol. 2012, 4, 1-5.

78. Carpio, C.; Escobar, F.; Batista-Viera, F.; Ruales, J. Bone-bound glucoamylase as a biocatalyst in bench-scale production of glucose syrups from liquefied cassava starch. Food Bioprocess Tech. 2011, 4, 566-577.

79. Zhao, G.; Wang, J.; Li, Y.; Huang, H.; Chen, X. Reversible immobilization of glucoamylase onto metal-ligand functionalized magnetic FeSBA-15. Biochem. Engin. J. 2012, 68, 159-166.

80. Singh, R.S.; Saini, G.K.; Kennedy, J.F. Covalent immobilization and thermodynamic characterization of pullulanase for the hydrolysis of pullulan in batch system. Carbohydr. Polym. 2010, 81, 252-259.

81. Singh, R.S.; Saini, G.K.; Kennedy, J.F. Maltotriose syrup preparation from pullulan using pullulanase. Carbohydr. Polym. 2010, 80, 401-407.

82. Talekar, S.; Ghodake, V.; Ghotage, T.; Rathod, P.; Deshmukh, P.; Nadar, S.; Mulla, M.; Ladole, M. Novel magnetic cross-linked enzyme aggregates (magnetic CLEAs) of alpha amylase. Bioresour. Technol. 2012, 123, 542-547.

83. Emregul, E.; Sungur, S.; Akbulut, U. Polyacrylamide-gelatine carrier system used for invertase immobilization. Food Chem. 2006, 97, 591-597.

84. Kotwal, S.M.; Shankar, V. Immobilized invertase. Biotechnol. Adv. 2009, 27, 311-322.

85. Cadena, P.G.; Wiggers, F.N.; Silva, R.A.; Lima Filho, J.L.; Pimentel, M.C.B. Kinetics and bioreactor studies of immobilized invertase on polyurethane rigid adhesive foam. Bioresour. Technol. 2011, 102, 513-518.

86. Smaali, I.; Soussi, A.; Bouallagui, H.; Chaira, N.; Hamdi, M.; Marzouki, M.N. Production of high-fructose syrup from date by-products in a packed bed bioreactor using a novel thermostable invertase from Aspergillus awamori. Biocatal. Biotransform. 2011, 29, 253-261.

87. Albertini, A.V.P.; Cadena, P.G.; Silva, J.L.; Nascimento, G.A.; Reis, A.L.S.; Freire, V.N.; Santos, R.P.; Martins, J.L.; Cavada, B.S.; Neto, P.J.R.; et al. Performance of invertase immobilized on glass-ceramic supports in batch bioreactor. Chem. Eng. J. 2012, 187, 341-350. 
88. Albertini, A.V.P.; Reis, A.L.S.; Teles, F.R.R.; Souza, J.C.; Filho, J.L.R.; Freire, V.N.; Santos, R.P.; Martins, J.L.; Cavada, B.S.; Martins, D.B.G.; et al. The new flow system approach in packed bed reactor applicable for immobilized enzyme. J. Mol. Catal. B Enzyme 2012, 79, 1-7.

89. Mirzarakhmetova, D.; Dekhkonov, D.; Rakhimov, M.; Abdurazakova, S.; Akhmedova, Z. The properties of invertase, covalently immobilized at activated carbon. Appl. Biochem. Microbiol. 2009, 45, 258-261.

90. Vujčić, Z.; Milovanović, A.; Božić, N.; Dojnov, B.; Vujčić, M.; Andjelković, U.; Lončar, N. Immobilization of cell wall invertase modified with glutaraldehyde for continuous production of invert sugar. J. Agric. Food Chem. 2010, 58, 11896-11900.

91. Mohd Zain, N.A.; Mohd Suardi, S.; Idris, A. Hydrolysis of liquid pineapple waste by invertase immobilized in PVA-alginate matrix. Biochem. Eng. J. 2010, 50, 83-89.

92. Talekar, S.; Shah, V.; Patil, S.; Nimbalkar, M. Porous cross linked enzyme aggregates (p-CLEAs) of Saccharomyces cerevisiae invertase. Catal. Sci. Technol. 2012, 2, 1575-1579.

93. Cho, Y.J.; Sinha, J.; Park, J.P.; Yun, J.W. Production of inulooligosaccharides from inulin by a dual endoinulinase system. Enzyme Microb. Technol. 2001, 29, 428-433.

94. Vandamme, E.J.; Derycke, D.G. Microbial Inulinases: Fermentation Process, Properties, and Applications. In Advances in Applied Microbiology, Allen, I.L., Ed.; Academic Press: New York, NY, USA, 1983; Volume 29, pp. 139-176.

95. Ricca, E.; Calabrò, V.; Curcio, S.; Iorio, G. The state of the art in the production of fructose from inulin enzymatic hydrolysis. Crit. Rev. Biotechnol. 2007, 27, 129-145.

96. Santa, G.; Bernardino, S.; Magalhães, S.; Mendes, V.; Marques, M.; Fonseca, L.; Fernandes, P. From inulin to fructose syrups using sol-gel immobilized inulinase. Appl. Biochem. Biotechnol. 2011, 165, 1-12.

97. Singh, R.; Dhaliwal, R.; Puri, M. Production of high fructose syrup from Asparagus inulin using immobilized exoinulinase from Kluyveromyces marxianus YS-1. J. Ind. Microbiol. Biotechnol. 2007, 34, 649-655.

98. Singh, R.; Dhaliwal, R.; Puri, M. Development of a stable continuous flow immobilized enzyme reactor for the hydrolysis of inulin. J. Ind. Microbiol. Biotechnol. 2008, 35, 777-782.

99. Ricca, E.; Calabrò, V.; Curcio, S.; Basso, A.; Gardossi, L.; Iorio, G. Fructose production by inulinase covalently immobilized on sepabeads in batch and fluidized bed bioreactor. Int. J. Mol. Sci. 2010, 11, 1180-1189.

100. De Paula, F.C.; Cazetta, M.L.; Monti, R.; Contiero, J. Sucrose hydrolysis by gelatin-immobilized inulinase from Kluyveromyces marxianus var. bulgaricus. Food Chem. 2008, 111, 691-695.

101. Ettalibi, M.; Baratti, J.C. Sucrose hydrolysis by thermostable immobilized inulinases from Aspergillus ficuum. Enzyme Microb. Technol. 2001, 28, 596-601.

102. Barranco-Florido, E.; García-Garibay, M.; Gómez-Ruiz, L.; Azaola, A. Immobilization system of Kluyveromyces marxianus cells in barium alginate for inulin hydrolysis. Process Biochem. 2001, 37, 513-519.

103. Makino, Y.; Lima, P.S.C.; Filho, F.M.; Rodrigues, M.I. Adsorption of the inulinase from Kluyveromyces marxianus NRRL Y-7571 on Streamline ${ }^{\circledR}$ DEAE resin. Braz. J. Chem. Eng. 2005, 22, 539-545. 
104. Nguyen, Q.D.; Rezessy-Szabó, J.M.; Czukor, B.; Hoschke, Á. Continuous production of oligofructose syrup from Jerusalem artichoke juice by immobilized endo-inulinase. Process Biochem. 2011, 46, 298-303.

105. Yun, J.W.; Park, J.P.; Song, C.H.; Lee, C.Y.; Kim, J.H.; Song, S.K. Continuous production of inulo-oligosaccharides from chicory juice by immobilized endoinulinase. Bioprocess Eng. 2000, 22, 189-194.

106. Spagna, G.; Pifferi, P.G.; Tramontini, M. Immobilization and stabilization of pectinlyase on synthetic polymers for application in the beverage industry. J. Mol. Catal. A Chem. 1995, 101, 99-105.

107. Wilson, B.; Strauss, C.R.; Williams, P.J. The distribution of free and glycosidically-bound monoterpenes among skin, juice, and pulp fractions of some white grape varieties. Am. J. Enol. Vitic. 1986, 37, 107-111.

108. Voirin, S.G.; Baumes, R.L.; Bitteur, S.M.; Gunata, Z.Y.; Bayonove, C.L. Novel monoterpene disaccharide glycosides of Vitis vinifera grapes. J. Agric. Food Chem. 1990, 38, 1373-1378.

109. Gueguen, Y.; Chemardin, P.; Janbon, G.; Arnaud, A.; Galzy, P. A very efficient beta-glucosidase catalyst for the hydrolysis of flavor precursors of wines and fruit juices. J. Agric. Food Chem. 1996, 44, 2336-2340.

110. Spagna, G.; Barbagallo, R.N.; Greco, E.; Manenti, I.; Pifferi, P.G. A mixture of purified glycosidases from Aspergillus niger for oenological application immobilised by inclusion in chitosan gels. Enzyme Microb. Technol. 2002, 30, 80-89.

111. Su, E.; Xia, T.; Gao, L.; Dai, Q.; Zhang, Z. Immobilization of $\beta$-glucosidase and its aroma-increasing effect on tea beverage. Food Bioprod. Process. 2010, 88, 83-89.

112. Figueira, J.A.; Dias, F.F.G.; Sato, H.H.; Fernandes, P. Screening of supports for the immobilization $\beta$-glucosidase. Enzyme Res. 2011, 2011, 8.

113. Whitaker, J.R. New and future uses of enzymes in food processing. Food Biotechnol. 1990, 4, 669-697.

114. Alaña, A.; Gabilondo, A.; Hernando, F.; Moragues, M.D.; Dominguez, J.B.; Llama, M.J.; Serra, J.L. Pectin lyase production by a penicillium italicum strain. Appl. Environ. Microbiol. 1989, 55, 1612-1616.

115. Lanzarini, G.; Pifferi, P.G. Enzymes in the Fruit Juice Industry. In Biotechnology Applications in Beverage Production; Cantarelli, C., Ed.; Elsevier Applied Science: New York, NY, USA, 1989.

116. Alkorta, I.; Garbisu, C.; María; Llama, J.; Serra, J.L. Immobilization of pectin lyase from Penicillium italicum by covalent binding to nylon. Enzyme Microb. Technol. 1996, 18, 141-146.

117. Torres, D.P.M.; Gonçalves, M.P.F.; Teixeira, J.A.; Rodrigues, L.R. Galacto-Oligosaccharides: Production, properties, applications, and significance as prebiotics. Compr. Rev. Food Sci. Food Saf. 2010, 9, 438-454.

118. Panesar, P.S.; Kumari, S.; Panesar, R. Potential applications of immobilized $\beta$-galactosidase in food processing industries. Enzyme Res. 2010, 2010, 1-16.

119. Boon, M.A.; Janssen, A.E.M.; van't Riet, K. Effect of temperature and enzyme origin on the enzymatic synthesis of oligosaccharides. Enzyme Microb. Technol. 2000, 26, 271-281. 
120. Boon, M.A.; Janssen, A.E.M.; van der Padt, A. Modelling and parameter estimation of the enzymatic synthesis of oligosaccharides by $\beta$-galactosidase from Bacillus circulans. Biotechnol. Bioeng. 1999, 64, 558-567.

121. Neri, D.F.M.; Balcão, V.M.; Costa, R.S.; Rocha, I.C.A.P.; Ferreira, E.M.F.C.; Torres, D.P.M.; Rodrigues, L.R.M.; Carvalho, L.B., Jr.; Teixeira, J.A. Galacto-oligosaccharides production during lactose hydrolysis by free Aspergillus oryzae $\beta$-galactosidase and immobilized on magnetic polysiloxane-polyvinyl alcohol. Food Chem. 2009, 115, 92-99.

122. Vera, C.; Guerrero, C.; Illanes, A.; Conejeros, R. A pseudo steady-state model for galacto-oligosaccharides synthesis with $\beta$-galactosidase from Aspergillus oryzae. Biotechnol. Bioeng. 2011, 108, 2270-2279.

123. Gosling, A.; Stevens, G.W.; Barber, A.R.; Kentish, S.E.; Gras, S.L. Effect of the substrate concentration and water activity on the yield and rate of the transfer reaction of $\beta$-galactosidase from Bacillus circulans. J. Agric. Food Chem. 2011, 59, 3366-3372.

124. Gaur, R.; Pant, H.; Jain, R.; Khare, S.K. Galacto-oligosaccharide synthesis by immobilized Aspergillus oryzae $\beta$-galactosidase. Food Chem. 2006, 97, 426-430.

125. Shin, H.-J.; Park, J.-M.; Yang, J.-W. Continuous production of galacto-oligosaccharides from lactose by Bullera singularis $\beta$-galactosidase immobilized in chitosan beads. Process Biochem. 1998, 33, 787-792.

126. Neri, D.F.M.; Balcão, V.M.; Dourado, F.O.Q.; Oliveira, J.M.B.; Carvalho, L.B., Jr.; Teixeira, J.A. Immobilized $\beta$-galactosidase onto magnetic particles coated with polyaniline: Support characterization and galactooligosaccharides production. J. Mol. Catal. B Enzyme 2011, $70,74-80$.

127. Liu, H.; Liu, J.; Tan, B.; Zhou, F.; Qin, Y.; Yang, R. Covalent immobilization of Kluyveromyces fragilis $\beta$-galactosidase on magnetic nanosized epoxy support for synthesis of galacto-oligosaccharide. Bioprocess Biosyst. Eng.2012, 35, 1287-1295.

128. Albayrak, N.; Yang, S.-T. Immobilization of $\beta$-galactosidase on fibrous matrix by polyethyleneimine for production of galacto-oligosaccharides from lactose. Biotechnol. Prog. 2002, 18, 240-251.

129. Güleç, H.; Gürdaş, S.; Albayrak, N.; Mutlu, M. Immobilization of Aspergillus oryzae $\beta$-galactosidase on low-pressure plasma-modified cellulose acetate membrane using polyethyleneimine for production of galactooligosaccharide. Biotechnol. Bioprocess Eng. 2010, 15, 1006-1015.

130. Nakkharat, P.; Haltrich, D. $\beta$-Galactosidase from Talaromyces thermophilus immobilized on to Eupergit $\mathrm{C}$ for production of galacto-oligosaccharides during lactose hydrolysis in batch and packed-bed reactor. World J. Microbiol. Biotechnol. 2007, 23, 759-764.

131. Zheng, P.; Yu, H.; Sun, Z.; Ni, Y.; Zhang, W.; Fan, Y.; Xu, Y. Production of galacto-oligosaccharides by immobilized recombinant $\beta$-galactosidase from Aspergillus candidus. Biotechnol. J. 2006, 1, 1464-1470.

132. Albayrak, N.; Yang, S.-T. Production of galacto-oligosaccharides from lactose by Aspergillus oryzae $\beta$-galactosidase immobilized on cotton cloth. Biotechnol. Bioeng. 2002, 77, 8-19. 
133. Mozaffar, Z.; Nakanishi, K.; Matsuno, R. Mechanism for reversible inactivation of immobilized $\beta$-galactosidase from Bacillus circulans during continuous production of galactooligosaccharides. Appl. Microbiol. Biotechnol. 1986, 25, 229-231.

134. Nakkharat, P.; Kulbe, K.D.; Yamabhai, M.; Haltrich, D. Formation of galacto-oligosaccharides during lactose hydrolysis by a novel $\beta$-galactosidase from the moderately thermophilic fungus Talaromyces thermophilus. Biotechnol. J. 2006, 1, 633-638.

135. Maiorano, A.; Piccoli, R.; da Silva, E.; de Andrade Rodrigues, M. Microbial production of fructosyltransferases for synthesis of pre-biotics. Biotechnol. Lett. 2008, 30, 1867-1877.

136. Alvarado-Huallanco, M.B.; Maugeri Filho, F. Kinetic studies and modelling of the production of fructooligosaccharides by fructosyltransferase from Rhodotorula sp. Catal. Sci. Technol. 2011, 1, 1043-1050.

137. Sánchez, O.; Rodriguez, A.; Silva, E.; Caicedo, L. Sucrose biotransformation to fructooligosaccharides by Aspergillus sp. N74 free cells. Food Bioprocess Tech. 2010, 3, 662-673.

138. Vaňková, K.; Onderková, Z.; Antošová, M.; Polakovič, M. Design and economics of industrial production of fructooligosaccharides. Chem. Pap. 2008, 62, 375-381.

139. Ning, Y.; Wang, J.; Chen, J.; Yang, N.; Jin, Z.; Xu, X. Production of neo-fructooligosaccharides using free-whole-cell biotransformation by Xanthophyllomyces dendrorhous. Bioresour. Technol. 2010, 101, 7472-7478.

140. Cruz, R.; Cruz, V.D.; Belini, M.Z.; Belote, J.G.; Vieira, C.R. Production of fructooligosaccharides by the mycelia of Aspergillus japonicus immobilized in calcium alginate. Bioresour. Technol. 1998, 65, 139-143.

141. Jung, K.H.; Bang, S.H.; Oh, T.K.; Park, H.J. Industrial production of fructooligosaccharides by immobilized cells of Aureobasidium pullulans in a packed bed reactor. Biotechnol. Lett. 2011, $33,1621-1624$.

142. Shin, H.T.; Park, K.M.; Kang, K.H.; Oh, D.J.; Lee, S.W.; Baig, S.Y.; Lee, J.H. Novel method for cell immobilization and its application for production of oligosaccharides from sucrose. Lett. Appl. Microbiol. 2004, 38, 176-179.

143. Smaali, I.; Jazzar, S.; Soussi, A.; Muzard, M.; Aubry, N.; Marzouki, M. Enzymatic synthesis of fructooligosaccharides from date by-products using an immobilized crude enzyme preparation of $\beta$-D-fructofuranosidase from Aspergillus awamori NBRC 4033. Biotechnol. Bioprocess Eng. 2012, 17, 385-392.

144. Kovaleva, T.; Holyavka, M.; Bogdanova, S. Inulinase immobilization on macroporous anion-exchange resins by different methods. Bull. Exp. Biol. Med. 2009, 148, 39-41.

145. Ghazi, I.; Segura, A.G.D.; Fernández-Arrojo, L.; Alcalde, M.; Yates, M.; Rojas-Cervantes, M.L.; Plou, F.J.; Ballesteros, A. Immobilisation of fructosyltransferase from Aspergillus aculeatus on epoxy-activated Sepabeads EC for the synthesis of fructo-oligosaccharides. J. Mol. Catal. B Enzyme $\mathbf{2 0 0 5}, 35,19-27$.

146. Alvarado-Huallanco, M.B.; Maugeri-Filho, F. Kinetics and modeling of fructooligosaccharide synthesis by immobilized fructosyltransferase from Rhodotorula sp. J. Chem. Technol. Biotechnol. 2010, 85, 1654-1662.

147. Husain, Q. $\beta$ Galactosidases and their potential applications: A review. Crit. Rev. Biotechnol. 2010, 30, 41-62. 
148. Guidini, C.Z.; Fischer, J.; Santana, L.N.S.; Cardoso, V.L.; Ribeiro, E.J. Immobilization of Aspergillus oryzae $\beta$-galactosidase in ion exchange resins by combined ionic-binding method and cross-linking. Biochem. Eng. J. 2010, 52, 137-143.

149. Pessela, B.C.C.; Fernandez-Lafuente, R.; Fuentes, M.; Vian, A.; Garca, J.L.; Carrascosa, A.V.; Mateo, C.; Guisan, J.M. Reversible immobilization of a thermophilic beta-galactosidase via ionic adsorption on PEI-coated Sepabeads. Enzyme Microb. Technol. 2003, 32, 369-374.

150. Pessela, B.C.C.; Mateo, C.; Fuentes, M.; Vian, A.; García, J.L.; Carrascosa, A.V.; Guisán, J.M.; Fernández-Lafuente, R. The immobilization of a thermophilic $\beta$-galactosidase on Sepabeads supports decreases product inhibition: Complete hydrolysis of lactose in dairy products. Enzyme Microb. Technol. 2003, 33, 199-205.

151. Mateo, C.; Monti, R.; Pessela, B.C.C.; Fuentes, M.; Torres, R.; Manuel Guisán, J.; Fernández-Lafuente, R. Immobilization of lactase from Kluyveromyces lactis greatly reduces the inhibition promoted by glucose. Full hydrolysis of lactose in milk. Biotechnol. Prog. 2004, 20, 1259-1262.

152. Tanriseven, A.; Doğan, Ş. A novel method for the immobilization of $\beta$-galactosidase. Process Biochem. 2002, 38, 27-30.

153. Jochems, P.; Satyawali, Y.; van Roy, S.; Doyen, W.; Diels, L.; Dejonghe, W. Characterization and optimization of $\beta$-galactosidase immobilization process on a mixed-matrix membrane. Enzyme Microb. Technol. 2011, 49, 580-588.

154. Takazoe, G. Palatinose-An Isomeric Alternative to Sucrose. In Progress in Sweeteners; Grenby, T.H., Ed., Elsevier: London, UK, 1989; pp. 143-167.

155. Sasaki, N.; Topitsoglou, V.; Takazoe, I.; Frostell, G. Cariogenicity of isomaltulose (palatinose), sucrose and mixture of these sugars in rats infected with Streptococcus mutans E-49. Swed. Dent. J. 1985, 9, 9149-9155.

156. Achten, J.; Jentjens, R.L.; Brouns, F.; Jeukendrup, A.E. Exogenous oxidation of isomaltulose is lower than that of sucrose during exercise in men. J. Nutr. 2007, 137, 1143-1148.

157. Contesini, F.J.; Ibarguren, C.; Grosso, C.R.F.; Carvalho, P.O.; Sato, H.H. Immobilization of glucosyltransferase from Erwinia sp. using two different techniques. J. Biotechnol. 2012, 158, $137-143$.

(C) 2013 by the authors; licensee MDPI, Basel, Switzerland. This article is an open access article distributed under the terms and conditions of the Creative Commons Attribution license (http://creativecommons.org/licenses/by/3.0/). 